\title{
Assessment of the Risk of Contamination of Food for Infants and Toddlers
}

\author{
Anita Mielech (D), Anna Puścion-Jakubik * (D) and Katarzyna Socha (D) \\ Department of Bromatology, Faculty of Pharmacy with the Division of Laboratory Medicine, \\ Medical University of Białystok, Mickiewicza 2D Street, 15-222 Białystok, Poland; \\ anita.mielech@umb.edu.pl (A.M.); katarzyna.socha@umb.edu.pl (K.S.) \\ * Correspondence: anna.puscion-jakubik@umb.edu.pl; Tel.: +48-8574-854-69
}

check for updates

Citation: Mielech, A.;

Puścion-Jakubik, A.; Socha, K.

Assessment of the Risk of

Contamination of Food for Infants

and Toddlers. Nutrients 2021, 13, 2358

https://doi.org/10.3390/nu13072358

Academic Editor: Veronica

Luque Moreno

Received: 25 April 2021

Accepted: 6 July 2021

Published: 9 July 2021

Publisher's Note: MDPI stays neutral with regard to jurisdictional claims in published maps and institutional affiliations.

Copyright: (c) 2021 by the authors. Licensee MDPI, Basel, Switzerland. This article is an open access article distributed under the terms and conditions of the Creative Commons Attribution (CC BY) license (https:/ / creativecommons.org/licenses/by/ $4.0 /)$.

\begin{abstract}
Infants and toddlers are highly sensitive to contaminants in food. Chronic exposure can lead to developmental delays, disorders of the nervous, urinary and immune systems, and to cardiovascular disease. A literature review was conducted mainly in PubMed, Google Scholar and Scopus databases, and took into consideration papers published from October 2020 to March 2021. We focused on contaminant content, intake estimates, and exposure to contaminants most commonly found in foods consumed by infants and children aged $0.5-3$ years. In the review, we included 83 publications with full access. Contaminants that pose a high health risk are toxic elements, acrylamide, bisphenol, and pesticide residues. Minor pollutants include: dioxins, mycotoxins, nitrates and nitrites, and polycyclic aromatic hydrocarbons. In order to reduce the negative health effects of food contamination, it seems reasonable to educate parents to limit foods that are potentially dangerous for infants and young children. An appropriate varied diet, selected cooking techniques, and proper food preparation can increase the likelihood that the foods children consume are safe for their health. It is necessary to monitor food contamination, adhere to high standards at every stage of production, and improve the quality of food for children.
\end{abstract}

Keywords: baby food; food contaminant; food safety

\section{Introduction}

Infants and young children are particularly vulnerable to contaminants in food because of the physiological characteristics that distinguish them from adults. Exposure to potentially toxic substances is especially dangerous because of infants' and young children's higher food intake (per kilogram of body weight- $\mathrm{kg} / \mathrm{bw}$ ), higher ventilation $(\mathrm{kg} / \mathrm{bw})$, and greater body surface area $(\mathrm{kg} / \mathrm{bw})$. Infants and toddlers have higher resting metabolic rates, which also contributes to greater sensitivity to toxins [1].

Non-food factors can also be a source of some contaminants such as toxic elements, which in the case of lead $(\mathrm{Pb})$ can account for up to $61 \%$ of the total intake. Most gastrointestinal functions develop by the first year of life, but intestinal motility remains slow, intestinal transit time is prolonged and the small intestine is incompletely developed, therefore absorption of toxic elements is higher compared to adults. The urinary and biliary systems also mature in the first year of life, while the mechanisms responsible for filtering and elimination of chemicals are not fully developed. In young children, the rate of gastric emptying is higher than in adults, resulting in more rapid absorption and higher peak serum concentrations [2]. Infants and young children are particularly susceptible to food contamination due to the high sensitivity of their digestive tract, and therefore intake limits for toxic substances should not be exceeded. Characteristics of contamination levels with selected compounds that are safe for infants and young children are presented in Table 1. 
Table 1. Characteristics of safe levels of contaminant intake for infants and toddlers [3-8].

\begin{tabular}{cc}
\hline Type of Contamination & Safe Contamination Levels \\
\hline Acrylamide & $\mathrm{RfD}=2 \mu \mathrm{g} / \mathrm{kg} / \mathrm{bw}$ \\
Arsenic & $\mathrm{PTWI}=15 \mu \mathrm{g} / \mathrm{kg} / \mathrm{bw}$ \\
Bisphenol A & $\mathrm{TDI}=50 \mu \mathrm{g} / \mathrm{kg} / \mathrm{bw}$ \\
Cadmium & $\mathrm{MTD}=4.1 \mu \mathrm{g} / \mathrm{day}, \mathrm{PTWI}=7 \mu \mathrm{g} / \mathrm{kg} / \mathrm{bw}$ \\
Dioxins & $\mathrm{TDI}=4 \mu \mathrm{g} / \mathrm{kg} / \mathrm{bw}, \mathrm{TWI}=2 \mathrm{pg} / \mathrm{kg} / \mathrm{bw}$ \\
Furan & $\mathrm{ADI}=2 \mu \mathrm{g} / \mathrm{kg} / \mathrm{bw}, \mathrm{RfD}=1 \mu \mathrm{g} / \mathrm{kg} / \mathrm{bw}$ \\
Lead & $\mathrm{MTD}=0.5 \mu \mathrm{g} / \mathrm{day}, \mathrm{PTWI}=25 \mu \mathrm{g} / \mathrm{kg} / \mathrm{bw}$ \\
Mercury & $\mathrm{PTWI}=1.6 \mu \mathrm{gg} / \mathrm{kg} / \mathrm{bw}$ \\
Mycotoxins & $\mathrm{MCL}_{\mathrm{aflatoxins}}=50 \mathrm{ng} / \mathrm{kg} / \mathrm{bw}$ \\
Nitrates, nitrites & $\mathrm{ADI}_{\text {total }}=0-3.7 \mathrm{mg} / \mathrm{kg} / \mathrm{bw}$ \\
Residue pesticides & $\mathrm{MRL}=0.1 \mathrm{mg} / \mathrm{kg} / \mathrm{bw}$ \\
\hline
\end{tabular}

ADI—Acceptable Daily Intake, bw—body weight, MCL—Maximum Consented Limit, MRL—Maximum Residue Limits, MTD—Maximum Tolerated Dose, PTWI—Provisional Tolerable Weekly Intake, RfD—Reference dose, TDI-Tolerable Daily Intake, TWI-Tolerable Weekly Intake.

Food for children should be a source of nutrients, vitamins, and minerals. It should also be free from contaminants that may adversely affect their health and development. Therefore, the aim of the study was to review the literature on selected contaminants in food intended for infants and young children and to assess the risk of its consumption.

\section{Materials and Methods}

This publication reviews research, published from 2004 to 2021, on risk assessment of food contaminants in infant and young child products. We focused on analysis of studies that considered such aspects as contaminant content, estimation of intake, and exposure to contaminants most frequently found in food consumed by children aged 0.5-3 years. We made a preliminary selection by searching the PubMed database and Google Scholar under the headings 'food safety', 'food contamination', and 'environmental contaminants'. On this basis, the most common contaminants in baby food were selected for inclusion in this review.

The literature review was mainly conducted in the PubMed database, as well as Google Scholar and Scopus, from October 2020 to March 2021. Studies with the largest numbers of trials were selected for consideration. The database was searched for 'contamination', 'baby food', 'infant formula', 'toxic elements', 'dioxins', 'acrylamide', 'bisphenol', 'furan', 'mycotoxins', 'nitrates', 'polycyclic aromatic hydrocarbon', 'pesticides', '3-MCPD', 'glycidyl esters', and 'mineral oil hydrocarbons'. The full texts of the selected papers were analyzed to assess whether they met the accepted criteria. Publications available in a language other than English were excluded.

The reference list of each article was searched to ensure that no important research articles were missed. Included clinical trials provide the latest evidence on food safety for infants and toddlers. No systematic review was undertaken, because this topic involves too many different groups of food contaminants.

This review discarded studies that involved animal measurements of contaminant concentrations, prenatal exposure, adult exposure to dietary contaminants, and contaminantexposed sick children. Research that analyzed conventional and infant foods as one group or estimated the risk of exposure to contaminants on the basis of a dietary record were also excluded. Other reasons for exclusion were: age group (under 6 months, over 3 years old), insufficient sample/study size, lack of full access, the study being a literature review, failure to specify products for children, inappropriate study material (e.g., human milk). Studies that did not serve the purpose of this review were also rejected.

\section{Results}

This paper presents the most important publications describing the current state of knowledge on risk assessment of contaminants in food for infants and toddlers. 
This review summarizes scientific evidence from the past 17 years. A total of 6278 studies were identified, 2880 duplicates were removed, 4298 related titles were chosen. Of these, full access was given to 146 publications, but 63 articles met the exclusion criteria, and 83 studies were eventually included in this review. More information about the search and selection process of studies is shown in Figure 1-based on Preferred Reporting Items for Systematic Reviews and Meta-Analyses (PRISMA) guidelines, with own modifications.

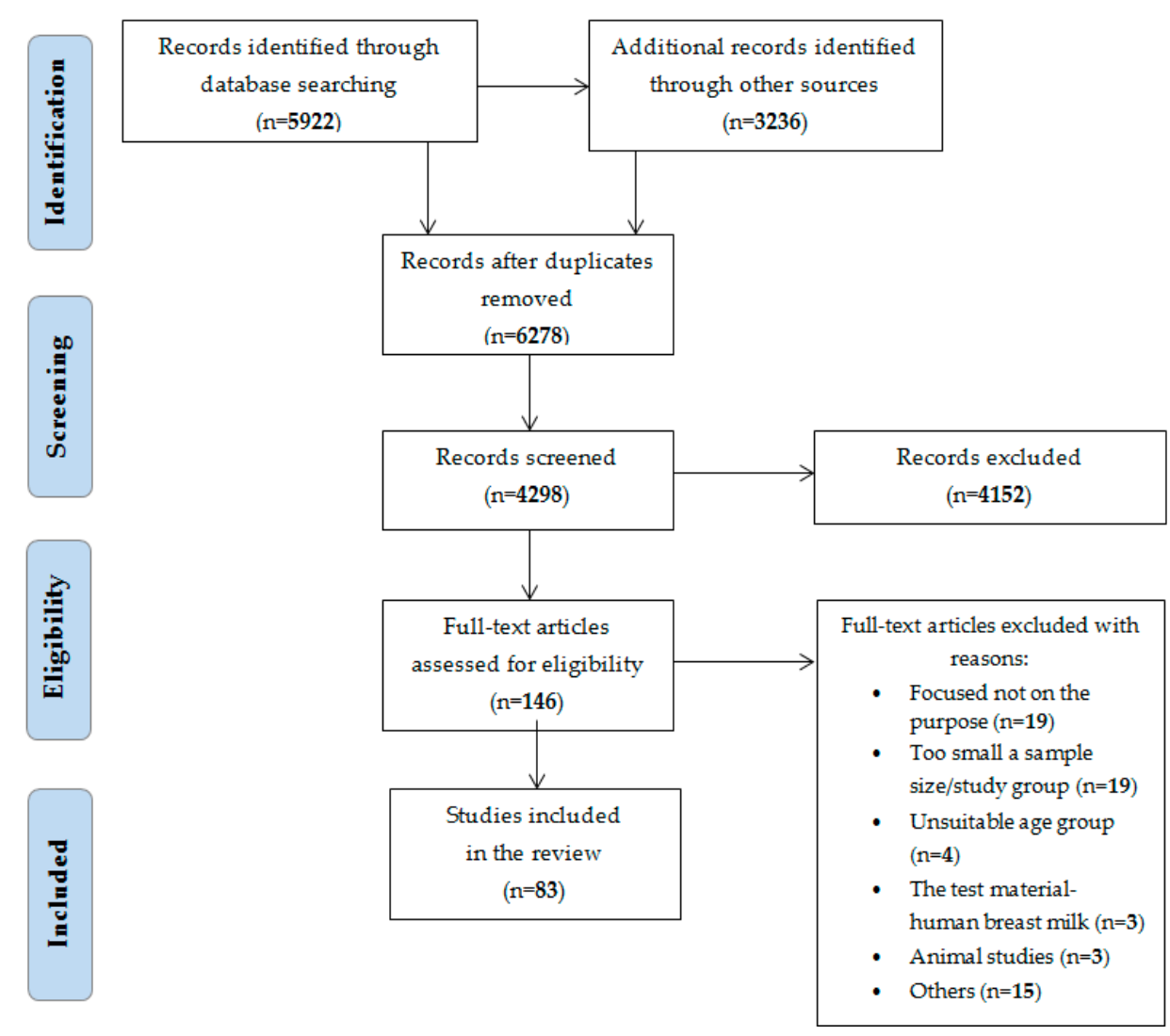

Figure 1. Preferred Reporting Items for Systematic Reviews and Meta-Analyses (PRISMA) flow diagram for studies retrieved through the searching and selection process with its own modifications.

\subsection{Toxic Elements}

A study by Igweze et al. (2020) found that $96 \%$ of infant formulas exceeded the daily allowable concentration of $\mathrm{Pb}(0.4 \mathrm{mg} / \mathrm{kg})$ and $53 \%$ exceeded the maximum $\mathrm{Cd}$ (cadmium) concentration $(0.1 \mathrm{mg} / \mathrm{kg}$ ), as per the Food and Drug Administration (FDA) standards [9]. Another study also reported $\mathrm{Pb}$ contamination in $37 \%$ of samples and $\mathrm{Cd}$ contamination in $57 \%$ of infant food samples. There was no significant difference in toxic element content between organic and conventional cultivation systems. Rice-based products contained significantly more $\mathrm{Pb}$ and $\mathrm{Cd}$ [10]. Some authors only detected $\mathrm{Pb}$ in individual samples [11,12]. In a Brazilian study evaluating $\mathrm{Pb}$ and $\mathrm{Cd}$ concentrations in infant formulas (formulas for particular nutritional uses for infants and breast milk substitutes), the median $\mathrm{Pb}$ concentration was $0.109 \mathrm{mg} / \mathrm{kg}$, exceeding the maximum standard set by the Food and Agriculture Organization of the United Nations/World Health Organization (FAO/WHO) $(0.02 \mathrm{mg} / \mathrm{kg})$. In addition, $\mathrm{Pb}$ concentrations in 7 infant formulas and 22 milk samples exceeded the Brazilian standard $(0.2 \mathrm{mg} / \mathrm{kg}$ in infant formula and $0.05 \mathrm{mg} / \mathrm{kg}$ in milk) [13].

In another study, $\mathrm{Cd}$ was detected in $65 \%$ of the samples, of which the highest amounts were found in potatoes, cookie cereal bars, vegetables, and bread. Additionally, $2.5 \%$ of children aged 3 years and under exceeded the TWI for Cd [14]. 
In contrast, a study by Gao et al. (2020) found no exceedance of Cd intake standards in snacks consumed by children aged 1-6 years. The estimated daily intake did not exceed the tolerable daily intake (maximum tolerable daily intake (MTDI) $=46 \mathrm{mg} / \mathrm{d}$ ). Among the studied snacks, the most $\mathrm{Cd}$ was observed in flour products (37\% of total Cd delivery from snacks) [15].

In a study analyzing $\mathrm{Hg}$ (mercury) content in 291 children's products, none of the samples exceeded the maximum allowable concentration. $\mathrm{Hg}$ was detected in prepared fish- and meat-based products (maximum concentration of $7.4 \mu \mathrm{g} / \mathrm{kg}$ ), in dairy desserts, cereal products and in one infant formula [16]. In contrast, in another study, fish products exceeded the maximum residue limits (MRL) for $\mathrm{Hg}(0.5-1.0 \mathrm{mg} / \mathrm{kg}$ ) in as many as $66 \%$ of all samples [17].

A study evaluating long-term exposure of children under 6 years to toxic elements reported that $\mathrm{Pb}$ exposure exceeded the reference value ( $\mathrm{RfT}=0.5 \mu \mathrm{g} / \mathrm{kg} \mathrm{bw}$ ) among $35 \%$ of children, $42 \%$ of children exceeded the TWI of $\mathrm{Cd}$, but $\mathrm{Hg}$ exposure was below the TWI. The main sources of $\mathrm{Pb}$ exposure were dairy products and vegetables, while in the case of $\mathrm{Cd}$ and $\mathrm{Hg}$, it was cereal products, fish, and shellfish [18]. Two of the analyzed studies also contain evidence to suggest that infant formulas are safe in terms of Pb content $[19,20]$.

A study evaluating arsenic (As) in infant foods found that $75 \%$ of samples were contaminated with inorganic As. The highest concentrations of As were found in rice noodles, whole grain rice, and crackers [21]. High As contamination was also reported by Rotenberg et al. (2017) and Ljung (2011) [22,23].

Another study evaluated the contents of $\mathrm{As}, \mathrm{Cd}, \mathrm{Hg}$, and $\mathrm{Pb}$ in infant foods. None of the products contained amounts of As which would pose a health risk. Oatmeal had the highest concentration of $\mathrm{Cd}(1.02 \mu \mathrm{g} / \mathrm{g})$, and fish had the highest concentrations of As and $\mathrm{Hg}(1.02 \mu \mathrm{g} / \mathrm{g}, 6 \mu \mathrm{g} / \mathrm{g}$, respectively) [24].

A summary of the studies on the concentration of toxic elements is shown in Table 2.

Table 2. Summary of studies on the safety of nitrates and nitrites in food for babies.

\begin{tabular}{|c|c|c|c|c|}
\hline $\begin{array}{c}\text { Type of } \\
\text { Contamination }\end{array}$ & $\begin{array}{l}\text { Number of } \\
\text { Samples }\end{array}$ & Type of Food Sample & Results & $\begin{array}{c}\text { Country } \\
\text { [Reference] }\end{array}$ \\
\hline \multicolumn{5}{|c|}{ CONTAMINANT CONTENT } \\
\hline Nitrites, nitrates & 1319 & $\begin{array}{l}{ }^{b} \text { Commercial food for } \\
\text { toddlers, }{ }^{c} \text { commercial food }\end{array}$ & $\begin{array}{c}\text { ADI of nitrite was exceeded in } 16 \% \\
\text { of infant and } 58 \% \text { of toddler food } \\
\text { samples }\end{array}$ & $\begin{array}{c}\text { France } \\
\text { [67] }\end{array}$ \\
\hline $\begin{array}{l}\text { Nitrites, nitrates, } \\
\text { N-nitrosoamines }\end{array}$ & 315 & $\begin{array}{l}\mathrm{b} \text { Commercial food for } \\
\text { toddlers (meat) }\end{array}$ & $\begin{array}{l}\text { ADI of nitrite was exceeded in } 40 \% \\
\text { and } 29 \% \text { of child food samples at } \\
\text { different times }\end{array}$ & $\begin{array}{l}\text { Estonia } \\
\text { [68] }\end{array}$ \\
\hline Nitrites, nitrates & 157 & $\begin{array}{l}{ }^{\mathrm{b}} \text { Commercial food for } \\
\text { toddlers (meat) }\end{array}$ & $\begin{array}{l}\text { ADI of nitrite was exceeded in } 3 \% \text { of } \\
\text { child food samples }\end{array}$ & $\begin{array}{c}\text { Estonia } \\
{[66]}\end{array}$ \\
\hline Nitrates, nitrites & 108 & $\begin{array}{l}{ }^{a} \text { Infant food, } \\
{ }^{c} \text { commercial food (vegetable, } \\
\text { fruit, cereals and milk based) }\end{array}$ & $\begin{array}{l}\text { Average nitrite content in the upper } \\
\text { limit of the standard }\end{array}$ & $\begin{array}{l}\text { Fiji } \\
{[65]}\end{array}$ \\
\hline \multicolumn{5}{|c|}{ ESTIMATION OF INTAKE } \\
\hline Nitrates & 1150 & $\begin{array}{l}\mathrm{b} \text { Commercial food for } \\
\text { toddlers (vegetable based), } \\
\text { vegetables }\end{array}$ & $\begin{array}{l}\text { No exceedance of the maximum } \\
\text { permissible dose }\end{array}$ & $\begin{array}{l}\text { Spain } \\
{[62]}\end{array}$ \\
\hline Nitrites, nitrates & 104 & $\begin{array}{l}\text { a Infant food, } \\
\text { c commercial food }\end{array}$ & $\begin{array}{l}\text { No exceedance of the maximum } \\
\text { permissible dose }\end{array}$ & $\begin{array}{l}\text { Italy } \\
{[63]}\end{array}$ \\
\hline Nitrates & 80 & $\begin{array}{c}\text { a Infant food } \\
\text { (vegetable based) }\end{array}$ & Only 1 sample exceeded the ADI & $\begin{array}{l}\text { Portugal } \\
\quad[61]\end{array}$ \\
\hline Nitrates & 39 & $\begin{array}{c}{ }^{\text {a }} \text { Infant food } \\
\text { (vegetable, meat- based) }\end{array}$ & $\begin{array}{l}\text { No exceedance of the maximum } \\
\text { permissible dose }\end{array}$ & $\begin{array}{l}\text { Portugal } \\
\text { [64] }\end{array}$ \\
\hline
\end{tabular}

ADI-Acceptable Daily Intake, ${ }^{a}$ Infant food—products intended for infants up to 12 months of age as complementary foods (cereals, desserts, mousses, wafers, etc.); all solid and liquid foods other than breast milk and infant formula for infants, ${ }^{\mathrm{b}}$ Commercial food for toddlers-snacks intended for children aged 12 to 36 months, ${ }^{c}$ Commercial food-food products intended for consumption by all age groups. 


\subsection{Acrylamide}

Abt et al. (2019) evaluated infant dietary exposure to acrylamide. Products intended for infants up to 12 months (e.g., snacks) had higher levels of acrylamide than jarred infant foods, suggesting the need to intensify acrylamide reduction processes during food production. The highest concentrations of acrylamide were observed in baby potato crisps, crackers, and breakfast cereals, i.e., complementary foods for infants and toddlers. The mean estimated intake of acrylamide for ages up to 2 years was $0.42 \mu \mathrm{g} / \mathrm{kg}$ bw $/$ day [25]. A large sample size study $(\mathrm{n}=2517)$ showed that the estimated dietary intake $(E D I=2 \mu \mathrm{g} / \mathrm{kg}$ body weight/day) was exceeded among 7\% of children aged 12-36 months. Acrylamide was identified as a potential hazard so reduction of this substance during processing is of utmost importance (Margin of Exposure - MOE < 10,000) [26].

In a study by Lambert et al. (2018), acrylamide was detected in 113 samples (80\%) and its mean concentrations varied from 0.14 to $102.00 \mu \mathrm{g} / \mathrm{kg}$. The highest value of acrylamide was found in infant cookies $(99.5 \mu \mathrm{g} / \mathrm{kg})$, potatoes with carrots $(67.0 \mu \mathrm{g} / \mathrm{kg})$, and potatoes with pumpkin $(67.0 \mu \mathrm{g} / \mathrm{kg})$ [27]. Elias et al. (2017) detected the highest concentrations of the substance in potato and cereal snacks. Above-limit concentrations of acrylamide were found primarily in plant-based infant foods. The mean value of acrylamide was $30-65 \mu \mathrm{g} / \mathrm{kg}$. High amounts of acrylamide in infant products entail serious health risks $(\mathrm{MOE}<10,000)$ [28]. In a study by Mojska et al. (2021), the average exposure of infants aged 6-12 months to this contaminant ranged from 2.1 to $4.3 \mu \mathrm{g} / \mathrm{kg} \mathrm{bw} /$ day, which exceeds the reference values. In addition, it was reported that the main sources of acrylamide were jarred baby meals (56.7\%) and follow-on infant formulas [29].

A summary of the studies on the concentration of acrylamide is presented in Table 3.

Table 3. Summary of studies on the safety of acrylamide in foods for babies.

\begin{tabular}{|c|c|c|c|c|}
\hline $\begin{array}{c}\text { Type of } \\
\text { Contamination }\end{array}$ & $\begin{array}{l}\text { Number of } \\
\text { Samples }\end{array}$ & Type of Food Sample & Results & $\begin{array}{c}\text { Country } \\
\text { [Reference] }\end{array}$ \\
\hline \multicolumn{5}{|c|}{ CONTAMINANT CONTENT } \\
\hline & 141 & $\begin{array}{l}\text { a Infant food, } \\
{ }^{c} \text { commercial food }\end{array}$ & $7 \%$ exceeded the RfD & $\begin{array}{l}\text { France } \\
\text { [26] }\end{array}$ \\
\hline \multirow[t]{2}{*}{ Acrylamide } & 141 & $\begin{array}{l}\text { a Infant food, } \\
\text { b commercial food for } \\
\text { toddlers }\end{array}$ & $\begin{array}{l}\text { Detected in } 80 \% \text { of samples, } \\
\text { exceeded the RfD }\end{array}$ & $\begin{array}{c}\text { France } \\
\text { [27] }\end{array}$ \\
\hline & 70 & $\begin{array}{l}\text { a Infant food, } \\
\text { c commercial food }\end{array}$ & Exceedance of RfD in baby food & $\begin{array}{c}\text { Estonia } \\
\text { [28] }\end{array}$ \\
\hline \multicolumn{5}{|c|}{ ESTIMATION OF INTAKE } \\
\hline \multirow{2}{*}{ Acrylamide } & 2517 & $\begin{array}{l}{ }^{\text {a }} \text { Infant food and } \\
{ }^{c} \text { commercial food }\end{array}$ & $\begin{array}{l}\text { Exposure of children twice as high } \\
\text { as that of adults }\end{array}$ & $\begin{array}{l}\text { USA } \\
{[25]}\end{array}$ \\
\hline & 111 & a Infant food & $\begin{array}{l}\text { Average intake by infants and } \\
\text { children exceeded RfD }\end{array}$ & $\begin{array}{l}\text { Poland } \\
\text { [29] }\end{array}$ \\
\hline
\end{tabular}

RfD—Reference Dose, a Infant food—products intended for infants up to 12 months of age as complementary foods (cereals, desserts, mousses, wafers, etc.); all solid and liquid foods other than breast milk and infant formula for infants, ${ }^{b}$ Commercial food for toddlerssnacks intended for children aged 12 to 36 months, ${ }^{c}$ Commercial food-food products intended for consumption by all age groups.

\subsection{Bisphenol}

In a study by Cao et al. (2009), bisphenol content was determined in 122 infant products packaged in jars and metal lids. Bisphenol was detected in 99 products, but its mean concentrations were mostly low (0.54-1.1 ng/g) [30]. In another study, bisphenol was detected in $38 \%$ of infant formula samples (mean concentration: $0.26 \mu \mathrm{g} / \mathrm{L}$ ) and in $76 \%$ of breast milk samples (mean concentration: $1.3 \mu \mathrm{g} / \mathrm{L}$ ) [31]. In Cirillo et al. (2015), bisphenol was found in $60 \%$ of baby foods and its mean concentration was $0.021 \mu \mathrm{g} / \mathrm{g}$. Both liquid and powdered products had similar bisphenol contents, suggesting that the substance came from manufacturing processes rather than food packaging [32]. In a study by Niu et al. 
(2007), bisphenol was detected in $36 \%$ of samples. Mean bisphenol exposure among infants up to 12 months of age exceeded the tolerable daily intake (TDI, $5-17 \mu \mathrm{g} / \mathrm{kg}$ bw/day). No exceedances of the TDI were reported among adults, confirming the higher risk of exposure among children [33]. Karsauliyta et al. (2021) studied the concentration of bisphenol analogues in infant formulas for 0- to 12-month-olds, in which they found exceedances to bisphenol [34]. The opposite result was obtained by Sun et al. (2017), who did not detect bisphenol in any of the analyzed 76 baby food samples [35].

A summary of the studies on the concentration of bisphenol A can be found in Table 4 .

Table 4. Summary of studies on the safety of bisphenol A in baby foods.

\begin{tabular}{|c|c|c|c|c|}
\hline $\begin{array}{c}\text { Type of } \\
\text { Contamination }\end{array}$ & $\begin{array}{l}\text { Number of } \\
\text { Samples }\end{array}$ & Type of Food Sample & Results & $\begin{array}{c}\text { Country } \\
\text { [Reference] }\end{array}$ \\
\hline \multicolumn{5}{|c|}{ CONTAMINANT CONTENT } \\
\hline \multirow{6}{*}{ Bisphenol A } & 154 & $\begin{array}{l}\mathrm{b} \text { Commercial food for } \\
\text { toddlers, }{ }^{\mathrm{d}} \text { commercial food }\end{array}$ & $\begin{array}{l}\text { Detected in } 36 \% \text { of infant food } \\
\text { samples, no TDI exceeded }\end{array}$ & $\begin{array}{c}\text { China } \\
\text { [33] }\end{array}$ \\
\hline & 122 & a Jarred infant food & $\begin{array}{l}\text { Detected in } 81 \% \text { of samples, no } \\
\text { MDL exceeded }\end{array}$ & $\begin{array}{l}\text { Canada } \\
\text { [30] }\end{array}$ \\
\hline & 103 & $\begin{array}{l}\text { Human milk and }{ }^{\mathrm{c}} \text { infant } \\
\text { formula }\end{array}$ & $\begin{array}{l}\text { Detected in } 38 \% \text { of infant food } \\
\text { samples, no RfD exceeded }\end{array}$ & $\begin{array}{c}\text { Spain } \\
{[31]}\end{array}$ \\
\hline & 76 & ${ }^{\mathrm{c}}$ Infant formula & None detected & $\begin{array}{c}\text { China } \\
\text { [35] }\end{array}$ \\
\hline & 68 & ${ }^{\mathrm{c}}$ Infant formula & $\begin{array}{c}\text { No bisphenol exceedances, no RfD } \\
\text { exceeded }\end{array}$ & $\begin{array}{l}\text { India } \\
{[34]}\end{array}$ \\
\hline & 50 & ${ }^{\mathrm{c}}$ Infant formula & $\begin{array}{c}\text { Detected in } 60 \% \text { of infant formula } \\
\text { samples }\end{array}$ & $\begin{array}{l}\text { Italy } \\
{[32]}\end{array}$ \\
\hline
\end{tabular}

RfD—Reference Dose, TDI-Tolerable Daily Intake, ${ }^{\text {a }}$ Infant food-products intended for infants up to 12 months of age as complementary foods (cereals, desserts, mousses, wafers, etc.); all solid and liquid foods other than breast milk and infant formula for infants, ${ }^{\mathrm{b}}$ Commercial food for toddlers—snacks intended for children aged 12 to 36 months, ${ }^{\mathrm{c}}$ Infant formula-food products intended for special dietary use solely for infants under 12 months of age as replacement human milk, ${ }^{d}$ Commercial food-food products intended for consumption by all age groups.

\subsection{Dioxins}

In a study by Saito et al. (2008), the dioxin content of infant food was evaluated. It was observed that the intake of dioxins in food was safe [36]. Lorán et al. (2010) concluded that dioxins in baby foods (cereal products, meat dishes, fish dishes) did not pose a health risk to infants [37]. Sasamoto et al. (2006) assessed that the main sources of dioxin were ready-made infant products and breast milk. The intake in all study groups (infants and young children from 5 to 15 months of age) was lower than the TDI (4 pg/kg/day) [38]. Similar observations were noted in other studies [39,40]. In Hulin et al. (2020), the dioxin content of traditional foods was higher than that of infant foods. In addition, the TDI was exceeded among children older than 6 months of age (exceedance of the TDI was $4.5 \%$ among children of 7-12 months and 5.1 to $7.4 \%$ among children of 13-36 months of age). It was estimated that approximately $96 \%$ of the food consumed by children contributed to dioxin exposure [41]. Research published by authors from Italy showed that children could safely consume the products under investigation [42].

A summary of the studies on the concentration of dioxins is shown in Table 5. 
Table 5. Summary of studies on the safety of dioxins in food for babies.

\begin{tabular}{|c|c|c|c|c|}
\hline $\begin{array}{c}\text { Type of } \\
\text { Contamination }\end{array}$ & $\begin{array}{l}\text { Number of } \\
\text { Samples }\end{array}$ & Type of Food Sample & Results & $\begin{array}{c}\text { Country } \\
\text { [Reference] }\end{array}$ \\
\hline \multicolumn{5}{|c|}{ CONTAMINANT CONTENT } \\
\hline Dioxins & 163 & $\begin{array}{c}\text { Commercial food, human milk, } \\
\text { infant } \\
\text { formula }\end{array}$ & $\begin{array}{l}\text { No exceedance of the upper limit of } \\
\text { the standard }\end{array}$ & $\begin{array}{l}\text { Greece } \\
\text { [40] }\end{array}$ \\
\hline \multicolumn{5}{|c|}{ ESTIMATION OF INTAKE } \\
\hline \multirow{4}{*}{ Dioxins } & 180 & $\begin{array}{c}\text { a Infant food, } \\
{ }^{b} \text { commercial food for toddlers }\end{array}$ & $\begin{array}{l}\text { TDI exceeded in children of } 7-12 \\
\text { months by } 4.5 \% \text {, in } 13-36 \text {-month- } \\
\text { olds by } 5.1-7.4 \%\end{array}$ & $\begin{array}{c}\text { France } \\
\text { [41] }\end{array}$ \\
\hline & 63 & $\begin{array}{l}\text { a Infant food, } \\
{ }^{\mathrm{b}} \text { commercial food for toddlers }\end{array}$ & Consumption is below the TWI & $\begin{array}{l}\text { Italy } \\
{[42]}\end{array}$ \\
\hline & 60 & $\begin{array}{l}\text { a Infant food, } \\
\text { c infant } \\
\text { formula }\end{array}$ & $\begin{array}{l}\text { No exceedance of the TDI in baby } \\
\text { food }\end{array}$ & $\begin{array}{l}\text { Germany } \\
\text { [39] }\end{array}$ \\
\hline & 16 & ${ }^{\text {a }}$ Infant food & $\begin{array}{l}\text { No exceedance of the TDI in baby } \\
\text { food }\end{array}$ & $\begin{array}{c}\text { Spain } \\
{[37]}\end{array}$ \\
\hline
\end{tabular}

TDI-Tolerable Daily Intake, TWI-Tolerable Weekly Intake, ${ }^{\text {a }}$ Infant food—products intended for infants up to 12 months of age as complementary foods (cereals, desserts, mousses, wafers, etc.); all solid and liquid foods other than breast milk and infant formula for infants, ${ }^{\mathrm{b}}$ Commercial food for toddlers—snacks intended for children aged 12 to 36 months, ${ }^{\mathrm{c}}$ Infant formula—food products intended for special dietary use solely for infants under 12 months of age as replacement human milk.

\subsection{Furan}

A study by Lambert et al. (2018) assessed furan content in samples of food for infants and children under 3 years of age. Furan was detected in 113 samples, with the highest amounts in spinach $(95 \mu \mathrm{g} / \mathrm{kg}$,) carrots, and ham $(73 \mu \mathrm{g} / \mathrm{kg})$ [43]. In another study, it was observed that heating in a microwave oven reduced furan content to $35 \%$, while using a water bath reduced it to $53 \%$. The highest amounts of furan were found in meatbased products $(7.9-61.0 \mathrm{ng} / \mathrm{g})$ and fish (19.0-84.0 ng/g) [44]. A significantly higher estimated daily intake of furan by infants $(0.333 \mu \mathrm{g} / \mathrm{kg})$ than by adults $(0.093 \mu \mathrm{g} / \mathrm{kg})$ was also observed. This is particularly worrisome since ready-made infant products are often a staple food during this period of life [45]. Similar results were obtained by Scholl et al. (2013), who also showed that infants had a significantly higher risk of furan exposure than adults [46]. In another paper, it was shown that the estimated dietary intake of furan among infants ranged from 0.03 to $3.56 \mu \mathrm{g} / \mathrm{kg}$ and exceeded the RfD reference standard $(0.1 \mu \mathrm{g} / \mathrm{kg})$ [47]. Liu demonstrated that the average concentration of furan in infant formulas ranged from 2.4 to $28.7 \mathrm{ng} / \mathrm{g}$, making infant products potentially hazardous to children's health [48].

Lachenmeier et al. (2009) estimated that the mean furan exposure among infants was $0.2 \mu \mathrm{g}$ per kg body weight a day, which is not a health risk. In addition, it was shown that in contrast to jarred infant foods, none of the home-prepared foods contained furan [49].

A summary of the studies on the concentration of furan can be found in Table 6. 
Table 6. Summary of studies on the safety of furan in food for babies.

\begin{tabular}{|c|c|c|c|c|}
\hline $\begin{array}{c}\text { Type of } \\
\text { Contamination }\end{array}$ & $\begin{array}{l}\text { Number of } \\
\text { Samples }\end{array}$ & Type of Food Sample & Results & $\begin{array}{c}\text { Country } \\
\text { [Reference] }\end{array}$ \\
\hline \multicolumn{5}{|c|}{ CONTAMINANT CONTENT } \\
\hline \multirow{2}{*}{ Furan } & 134 & $\begin{array}{l}\text { a Infant food, } \\
{ }^{\mathrm{b}} \text { commercial food for toddlers }\end{array}$ & Furan found in $84 \%$ of samples & $\begin{array}{l}\text { France } \\
\text { [43] }\end{array}$ \\
\hline & 101 & ${ }^{\mathrm{b}}$ Commercial food for toddlers & Contamination of $12 \%$ of samples & $\begin{array}{l}\text { Taiwan } \\
\text { [48] }\end{array}$ \\
\hline \multicolumn{5}{|c|}{ ESTIMATION OF INTAKE } \\
\hline \multirow{5}{*}{ Furan } & 301 & a Infant food & EDI exceeded reference dose & $\begin{array}{l}\text { Poland } \\
\text { [47] }\end{array}$ \\
\hline & 191 & $\begin{array}{l}{ }^{\mathrm{b}} \text { Commercial food for toddlers, } \\
{ }^{\mathrm{c}} \text { commercial food }\end{array}$ & $\begin{array}{l}\text { EDI about } 3 \text { times higher among } \\
\text { infants than adults }\end{array}$ & $\begin{array}{c}\text { China } \\
{[45]}\end{array}$ \\
\hline & 78 & $\begin{array}{l}{ }^{a} \text { Infant food, } \\
\text { b commercial food for } \\
\text { toddlers }\end{array}$ & $\begin{array}{l}\text { EDI } 3.8 \text { times higher among } \\
\text { infants than adults }\end{array}$ & $\begin{array}{l}\text { Belgium } \\
\text { [46] }\end{array}$ \\
\hline & \multicolumn{3}{|c|}{ EXPOSURE } & \\
\hline & 230 & $\begin{array}{l}\text { a Infant food, } \\
{ }^{b} \text { commercial food for toddlers }\end{array}$ & $\begin{array}{l}\text { Medium exposure is not a health } \\
\text { risk }\end{array}$ & $\begin{array}{l}\text { Germany } \\
\text { [49] }\end{array}$ \\
\hline Furan & 76 & $\begin{array}{l}\text { a Infant food, } \\
{ }^{b} \text { commercial food for toddlers }\end{array}$ & $\begin{array}{c}\text { Meat- and fish-based products } \\
\text { potential risk for } \\
\text { children }\end{array}$ & $\begin{array}{l}\text { Spain } \\
{[44]}\end{array}$ \\
\hline
\end{tabular}

EDI-Estimated Daily Intake, a Infant food—products intended for infants up to 12 months of age as complementary foods (cereals, desserts, mousses, wafers, etc.); all solid and liquid foods other than breast milk and infant formula for infants, ${ }^{\mathrm{b}}$ Commercial food for toddlers—snacks intended for children aged 12 to 36 months, ${ }^{c}$ Commercial food-food products intended for consumption by all age groups.

\subsection{Mycotoxins}

In a study by Mallmann et al. (2020), mycotoxins were detected in $31 \%$ of cereal product samples and in $19 \%$ of infant cereal porridge samples. In addition, co-occurrence of 2 or more mycotoxins was found in $31 \%$ of cereals and $19 \%$ of infant cereals. The most frequently detected mycotoxins were fumonisins $(26.7 \%)$ and zearalenone $(14.8 \%)$ [50]. Saleh et al. (2019) evaluated patulin content in apple-based products for children. Estimated daily intake did not exceed the maximum TDI, i.e., $0.4 \mu \mathrm{g} / \mathrm{kg}$ bw/day. The most exposed group were children under 6 years of age [51]. In contrast, another study detected aflatoxins in $20 \%$ of the samples (aflatoxin B1), of which $10 \%$ exceeded the maximum tolerable concentration $(0.1 \mu \mathrm{g} / \mathrm{kg})$. There were no differences between whole grain products and refined cereal products, while organic cereal products contained higher concentrations of deoxynivalenol than conventional products [52]. In a study by Postupolski et al. (2019), none of the 302 samples of cereal products for children exceeded the TDI. For medium exposure, the values were up to $3 \%$, while for high exposure, up to $10 \%$ of the reference values (mainly deoxynivalenol and fumonisins) [53]. In another study, ochratoxins were found in $41 \%$ of cereal products for children, the average level being $0.42 \pm 0.27 \mu \mathrm{g} / \mathrm{kg}$. It was observed that $7.8 \%$ of the samples exceeded the highest permissible ochratoxin concentration recommended by the European Commission $(0.5 \mu \mathrm{g} / \mathrm{kg})$. The highest ochratoxin contamination was found in rice-based infant products $(57 \%)$, wheat $(23 \%)$, and multi-grain products (20\%) [54]. In another study, aflatoxin and fumonisin contamination concerned $42 \%$ of all cereal- and nut-based products. Mycotoxin exposure exceeded reference values, indicating a health risk to infants and young children [55]. In another study, $85 \%$ of the analyzed infant formula samples exceeded the maximum tolerance limit (MTL) [56]. In Sundheimet al. (2017), the highest concentration of deoxynvalenol (DON) mycotoxin was observed among children aged 2 years, which was associated with high consumption of cereal products. The average exposure was twice the TDI [57]. 
There are also studies which indicate that the risk from mycotoxins in infant formulas is negligible [58-60]. In conclusion, contamination is rare and cereal products for infants and young children appear to be safe.

A summary of the studies on the concentration of mycotoxins is presented in Table 7.

Table 7. Summary of studies on the safety of mycotoxins in food for babies.

\begin{tabular}{|c|c|c|c|c|}
\hline $\begin{array}{c}\text { Type of } \\
\text { Contamination } \\
\text { (Number of } \\
\text { Mycotoxins Tested) }\end{array}$ & $\begin{array}{l}\text { Number of } \\
\text { Samples }\end{array}$ & Type of Food Sample & Results & $\begin{array}{c}\text { Country } \\
\text { [Reference] }\end{array}$ \\
\hline \multicolumn{5}{|c|}{ CONTAMINANT CONTENT } \\
\hline Mycotoxins & 1207 & ${ }^{\mathrm{c}}$ Infant formula, milk & $\begin{array}{c}\text { Only } 1 \% \text { of samples exceeded } \\
\text { the norm }\end{array}$ & $\begin{array}{l}\text { China } \\
{[60]}\end{array}$ \\
\hline $\begin{array}{l}\text { Mycotoxins } \\
\text { (14) }\end{array}$ & 215 & $\begin{array}{l}\text { a Infant food } \\
\text { (cereal products) }\end{array}$ & $\begin{array}{l}\text { Contamination of } 31 \% \text { of } \\
\text { cereals, } 19 \% \text { of baby cereals; } \\
\text { norms were exceeded }\end{array}$ & $\begin{array}{c}\text { Brazil } \\
{[51]}\end{array}$ \\
\hline $\begin{array}{c}\text { Mycotoxins } \\
\text { (1: aflatoxin M1) }\end{array}$ & 185 & $\begin{array}{l}\text { a Infant food (dairy } \\
\text { products), }{ }^{c} \text { infant } \\
\text { formula }\end{array}$ & $\begin{array}{l}85 \% \text { of infant formula samples } \\
\text { exceeded the MCL }\end{array}$ & $\begin{array}{l}\text { Jordan } \\
\text { [54] }\end{array}$ \\
\hline $\begin{array}{l}\text { Mycotoxins } \\
\text { (5) }\end{array}$ & 137 & $\begin{array}{l}{ }^{a} \text { Infant food } \\
\text { (cereal and nuts } \\
\text { products) }\end{array}$ & $\begin{array}{l}\text { Contamination of } 42 \% \text { of baby } \\
\text { food samples }\end{array}$ & $\begin{array}{l}\text { Nigeria } \\
\text { [56] }\end{array}$ \\
\hline $\begin{array}{c}\text { Mycotoxins } \\
\text { (1: aflatoxin M1) }\end{array}$ & 101 & $\begin{array}{l}\text { a Infant food } \\
\text { (dairy products), } \\
{ }^{c} \text { infant formula }\end{array}$ & $\begin{array}{l}1 \text { sample of infant formula } \\
\text { contaminated }\end{array}$ & $\begin{array}{l}\text { Serbia } \\
{[59]}\end{array}$ \\
\hline $\begin{array}{c}\text { Mycotoxins } \\
\text { (1: aflatoxin M1) }\end{array}$ & 84 & ${ }^{\mathrm{c}}$ Infant formula & $\begin{array}{l}\text { Contamination of } 3 \% \text { of } \\
\text { samples, norms were not } \\
\text { exceeded }\end{array}$ & $\begin{array}{l}\text { Turkey } \\
\text { [58] }\end{array}$ \\
\hline $\begin{array}{c}\text { Mycotoxins } \\
\text { (1: ochratoxin A) }\end{array}$ & 64 & $\begin{array}{c}{ }^{\mathrm{a}} \text { Infant food } \\
\text { (cereal products) }\end{array}$ & $\begin{array}{l}\text { Contamination of } 41 \% \text { of cereal } \\
\text { samples }\end{array}$ & $\begin{array}{l}\text { Iran } \\
{[55]}\end{array}$ \\
\hline $\begin{array}{l}\text { Mycotoxins } \\
\text { (5) }\end{array}$ & 60 & $\begin{array}{l}{ }^{a} \text { Infant food } \\
\text { (cereal products) }\end{array}$ & $\begin{array}{c}\text { Contamination of } 20 \% \text { of cereal } \\
\text { samples, of which } 10 \% \\
\text { exceeded maximum level }\end{array}$ & $\begin{array}{l}\text { Spain } \\
{[52]}\end{array}$ \\
\hline \multicolumn{5}{|c|}{ ESTIMATION OF INTAKE } \\
\hline $\begin{array}{c}\text { Mycotoxin } \\
\text { (1: Deoxynivalenol) }\end{array}$ & 3309 & $\begin{array}{l}\text { a Infant food, } \\
\text { c infant formula, milk }\end{array}$ & $\begin{array}{c}\text { Average exposure twice as } \\
\text { high as TDI }\end{array}$ & $\begin{array}{l}\text { Norway } \\
\text { [57] }\end{array}$ \\
\hline $\begin{array}{l}\text { Mycotoxins } \\
\text { (1: patulin) }\end{array}$ & 610 & $\begin{array}{l}\text { b Commercial food for } \\
\text { toddlers } \\
\text { (apple-based products) }\end{array}$ & $\begin{array}{l}\text { No exceedances of PMTDI } \\
\text { standards }\end{array}$ & $\begin{array}{l}\text { Qatar } \\
{[50]}\end{array}$ \\
\hline $\begin{array}{l}\text { Mycotoxins } \\
\text { (5) }\end{array}$ & 302 & $\begin{array}{l}{ }^{a} \text { Infant food and }{ }^{b} \\
\text { commercial food for } \\
\text { toddlers } \\
\text { (cereal products) }\end{array}$ & $\begin{array}{l}\text { No exceedances of TDI } \\
\text { standards }\end{array}$ & $\begin{array}{l}\text { Poland } \\
\text { [53] }\end{array}$ \\
\hline
\end{tabular}

MCL—Maximum Contaminant Level, PMTDI—Provisional Maximum Tolerable Daily Intake, TDI—Tolerable Daily Intake, ${ }^{\text {a }}$ Infant foodproducts intended for infants up to 12 months of age as complementary foods (cereals, desserts, mousses, wafers, etc.); all solid and liquid foods other than breast milk and infant formula for infants, ${ }^{b}$ Commercial food for toddlers—snacks intended for children aged 12 to 36 months,

${ }^{\mathrm{c}}$ Infant formula-food products intended for special dietary use solely for infants under 12 months of age as replacement human milk.

\subsection{Nitrates and Nitrites}

A study by Vasco et al. (2011) analyzed the nitrate content of foods for children (processed vegetables, fruit, juices) from organic and conventional farming. Only one sample exceeded the acceptable daily intake. Additionally, no differences were noted between nitrate concentrations in foods obtained using different farming methods [61]. In another large study $(n=1150)$, none of the infant products analyzed exceeded the 
maximum acceptable nitrate level. The estimated daily intake of nitrates by infants and children over 1 year of age was $13 \%$ and $18 \%$ of the ADI, respectively [62].

On the other hand, in a study by Cortesi et al. (2014), no exceedance of the maximum allowable nitrate concentration $(200 \mathrm{mg} / \mathrm{kg} \mathrm{bw})$ was recorded in the analyzed samples [63]. Similar observations were also made by other researchers [64]. Another study reported single exceedances of the maximum allowable nitrate concentration in vegetable preparations for this age group, with the mean nitrate concentration equal to the upper limit of the standard (189 mg/kg bw) [65]. In a study by Elias et al. (2020), where the source of nitrates and nitrites were the most common processed meat products, the exceedance of ADI was reported in 3\% of children [66]. Mancini et al. (2014) showed significant exceedances of the ADI of nitrite content in food for children of 7-12 months and 13-36 months by $16 \%$ and $58 \%$, respectively. Meat was the main source of high nitrite concentrations. Considering the whole study population, the average intake of nitrites was lower than the ADI, confirming the fact that infants and children are the group that is most exposed to nitrites in food [67]. Similar observations were noted for a smaller group of subjects [68].

A summary of the studies on the concentration of nitrates and nitrites is shown in Table 8.

Table 8. Summary of studies on the safety of nitrates and nitrites in food for babies.

\begin{tabular}{|c|c|c|c|c|}
\hline $\begin{array}{c}\text { Type of } \\
\text { Contamination }\end{array}$ & $\begin{array}{l}\text { Number of } \\
\text { Samples }\end{array}$ & Type of Food Sample & Results & $\begin{array}{c}\text { Country } \\
\text { [Reference] }\end{array}$ \\
\hline \multicolumn{5}{|c|}{ CONTAMINANT CONTENT } \\
\hline Nitrites, nitrates & 1319 & $\begin{array}{l}{ }^{\mathrm{b}} \text { Commercial food for } \\
\text { toddlers, }{ }^{\mathrm{c}} \text { commercial } \\
\text { food }\end{array}$ & $\begin{array}{c}\text { ADI of nitrite was exceeded in } 16 \% \\
\text { of infant and } 58 \% \text { of toddler food } \\
\text { samples }\end{array}$ & $\begin{array}{l}\text { France } \\
\text { [67] }\end{array}$ \\
\hline $\begin{array}{l}\text { Nitrites, nitrates, } \\
\text { N-nitrosoamines }\end{array}$ & 315 & $\begin{array}{l}{ }^{\mathrm{b}} \text { Commercial food for } \\
\text { toddlers (meat) }\end{array}$ & $\begin{array}{l}\text { ADI of nitrite was exceeded in } 40 \% \\
\text { and } 29 \% \text { of child food samples at } \\
\text { different times }\end{array}$ & $\begin{array}{l}\text { Estonia } \\
\text { [68] }\end{array}$ \\
\hline Nitrites, nitrates & 157 & $\begin{array}{l}{ }^{\mathrm{b}} \text { Commercial food for } \\
\text { toddlers (meat) }\end{array}$ & $\begin{array}{l}\text { ADI of nitrite was exceeded in 3\% of } \\
\text { child food samples }\end{array}$ & $\begin{array}{c}\text { Estonia } \\
\text { [66] }\end{array}$ \\
\hline Nitrates, nitrites & 108 & $\begin{array}{l}\text { a Infant food, } \\
\text { c commercial food } \\
\text { (vegetable, fruit, cereals } \\
\text { and milk based) }\end{array}$ & $\begin{array}{l}\text { Average nitrite content in the upper } \\
\text { limit of the standard }\end{array}$ & $\begin{array}{l}\text { Fiji } \\
{[65]}\end{array}$ \\
\hline \multicolumn{5}{|c|}{ ESTIMATION OF INTAKE } \\
\hline Nitrates & 1150 & $\begin{array}{l}{ }^{\mathrm{b}} \text { Commercial food for } \\
\text { toddlers (vegetable based), } \\
\text { vegetables }\end{array}$ & $\begin{array}{l}\text { No exceedance of the maximum } \\
\text { permissible dose }\end{array}$ & $\begin{array}{c}\text { Spain } \\
{[62]}\end{array}$ \\
\hline Nitrites, nitrates & 104 & $\begin{array}{l}\text { a Infant food, } \\
\text { c commercial food }\end{array}$ & $\begin{array}{l}\text { No exceedance of the maximum } \\
\text { permissible dose }\end{array}$ & $\begin{array}{l}\text { Italy } \\
{[63]}\end{array}$ \\
\hline Nitrates & 80 & $\begin{array}{c}\text { a Infant food } \\
\text { (vegetable based) }\end{array}$ & Only 1 sample exceeded the ADI & $\begin{array}{l}\text { Portugal } \\
\quad[61]\end{array}$ \\
\hline Nitrates & 39 & $\begin{array}{c}{ }^{\mathrm{a}} \text { Infant food } \\
\text { (vegetable, meat- based) }\end{array}$ & $\begin{array}{l}\text { No exceedance of the maximum } \\
\text { permissible dose }\end{array}$ & $\begin{array}{l}\text { Portugal } \\
\text { [64] }\end{array}$ \\
\hline
\end{tabular}

ADI-Acceptable Daily Intake, ${ }^{\text {a }}$ Infant food—products intended for infants up to 12 months of age as complementary foods (cereals, desserts, mousses, wafers, etc.); all solid and liquid foods other than breast milk and infant formula for infants, ${ }^{\mathrm{b}}$ Commercial food for toddlers-snacks intended for children aged 12 to 36 months, ${ }^{\mathrm{C}}$ Commercial food-food products intended for consumption by all age groups.

\subsection{Pesticide Residues}

A study by Nougadere et al. (2020) evaluated pesticide content in foods for children under 3 years of age and in commercial foods. Pesticide residues were detected in $67 \%$ of samples (78 different pesticides). Among the most frequently detected were fungicides, 2-phenylphenol, boscalid, azoxystrobin, captan, and tetrahydrophthalimide [69]. Similar results were obtained by Stepan et al. (2005), who found pesticides in $60 \%$ of all analyzed 
samples. In infant fruit foods, pesticide residues were found in $16 \%$ of samples, with maximum residue levels $(0.01 \mathrm{mg} / \mathrm{kg})$ exceeded in $9 \%$ of them. The most common pesticides were organophosphorus insecticides and fungicides, represented by phtalimides, dicarboximides, and sulphamides [70]. In a study by Jeong et al. (2014), at least 1 pesticide was detected in every sample. It was reported that the average concentration of organochlorine pesticides was 2 times higher in foods for 15-month-olds than in products for 6-montholds [71]. In a study by Torović et al. (2020), pesticides were detected in $56 \%$ of infant food samples. In addition, more domestic products $(85 \%)$ than imported products $(38 \%)$ had high pesticide contents [72]. Kapoor et al. (2012) evaluated the content of imidacloprid, an alternative to organochlorine pesticides. Imidacloprid was found in $15 \%$ of the samples, of which 3\% exceeded the MRL [73]. Gilbert-Lòpez et al. (2007) assessed the content of 12 pesticides in baby food containing fruit. The detection limit of the developed method ranged from 0.1 (imazalil) to $4 \mu \mathrm{g} / \mathrm{kg}$ (iprodione). Despite the fact that three pesticides (carbendazim, imazalil, and thianendazole) were detected in approximately $60 \%$ of the samples, none exceeded the limit of $0.01 \mathrm{mg} / \mathrm{kg}$ [74]. One more recent study, published by Panseri et al. (2020), found perchlorate in $10.5 \%$ of the baby food and commercial food samples the authors tested [75].

Table 9 summarizes the studies on pesticides in baby food.

Table 9. Summary of studies on the safety of pesticide residues in food for babies.

\begin{tabular}{|c|c|c|c|c|}
\hline $\begin{array}{c}\text { Type of } \\
\text { Contamination } \\
\text { (Number of } \\
\text { Pesticides Tested) }\end{array}$ & $\begin{array}{l}\text { Number } \\
\text { of } \\
\text { Samples }\end{array}$ & Type of Food Sample & Results & $\begin{array}{c}\text { Country } \\
\text { [Reference] }\end{array}$ \\
\hline \multicolumn{5}{|c|}{ CONTAMINANT CONTENT } \\
\hline $\begin{array}{l}\text { Pesticides } \\
\quad(86)\end{array}$ & 522 & $\begin{array}{l}\text { a Infant food } \\
\text { (fruit based) }\end{array}$ & $\begin{array}{l}\text { Detected in } 60 \% \text { of samples, } \\
1.4 \% \text { exceeded the MRL }\end{array}$ & $\begin{array}{c}\text { Czech Republic } \\
\text { [70] }\end{array}$ \\
\hline $\begin{array}{l}\text { Pesticides } \\
\quad(516)\end{array}$ & 309 & $\begin{array}{l}\text { b Commercial food for } \\
\text { toddlers, }{ }^{c} \text { commercial food }\end{array}$ & $\begin{array}{c}\text { Detected in } 67 \% \text { of samples, } \\
\text { exceeded the TRV }\end{array}$ & $\begin{array}{c}\text { France } \\
\text { [69] }\end{array}$ \\
\hline $\begin{array}{c}\text { Pesticides: } \\
\text { (1: imidacloprid) }\end{array}$ & 250 & $\begin{array}{l}\text { a Infant food, fruit, } \\
\text { vegetables, cereal }\end{array}$ & $\begin{array}{l}\text { Detected in } 15 \% \text { of samples, } \\
\text { exceeded the MRL }\end{array}$ & $\begin{array}{c}\text { India } \\
{[72]}\end{array}$ \\
\hline $\begin{array}{c}\text { Pesticides } \\
\text { (4: glyphosate, glufosinate, } \\
\text { perchlorate, } \\
\text { chlorate) }\end{array}$ & 105 & $\begin{array}{l}\text { a Infant food, } \\
{ }^{c} \text { commercial food }\end{array}$ & $\begin{array}{l}\text { Perchlorate detected in } 10.5 \% \\
\text { of samples }\end{array}$ & $\begin{array}{l}\text { Italy } \\
{[75]}\end{array}$ \\
\hline $\begin{array}{l}\text { Pesticides } \\
\text { (18) }\end{array}$ & 100 & $\begin{array}{l}{ }^{\mathrm{c}} \text { Commercial food } \\
\text { (homemade) }\end{array}$ & Detected in $100 \%$ of samples & $\begin{array}{c}\text { Korea } \\
{[71]}\end{array}$ \\
\hline $\begin{array}{l}\text { Pesticides } \\
\text { (69) }\end{array}$ & 54 & $\begin{array}{l}\text { a Infant food } \\
\text { (juices, purees) }\end{array}$ & Detected in $56 \%$ of samples & $\begin{array}{c}\text { Serbia } \\
{[72]}\end{array}$ \\
\hline $\begin{array}{l}\text { Pesticides } \\
\quad(12)\end{array}$ & 33 & $\begin{array}{l}\text { a Infant food } \\
\text { (juices, multi-fruit jars) }\end{array}$ & $\begin{array}{l}\text { Three pesticides detected in } \\
60 \% \text { of samples }\end{array}$ & $\begin{array}{c}\text { Spain and United } \\
\text { Kingdom } \\
\text { [74] }\end{array}$ \\
\hline
\end{tabular}

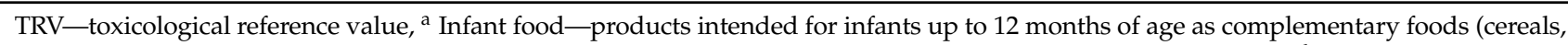
desserts, mousses, wafers, etc.); all solid and liquid foods other than breast milk and infant formula for infants, ${ }^{b}$ Commercial food for toddlers—snacks intended for children aged 12 to 36 months, ${ }^{c}$ Commercial food-food products intended for consumption by all age groups.

\subsection{Polycyclic Aromatic Hydrocarbon (PAH)}

Dairy products showed higher PAH concentrations than meat- and fish-based products. In low-fat products (up to 3\% fat), PAH concentrations were lower $(19.4 \mu \mathrm{g} / \mathrm{kg}$ ) than in products with higher fat content $(43.3 \mu \mathrm{g} / \mathrm{kg})$. PAH norms were exceeded in milk based products in $18.2 \%$ (benzopyrene) and $77.7 \%$ ( $\mathrm{PPAH} 4)$ of samples and also in meat- and fish-based products (5.6\% and $44.4 \%$ respectively) [76]. Similar observations were made by Di Bella et al. (2020), where exceedances were reported in the PAH content of dairy 
products: cow milk (mean content $12.56 \mathrm{ng} / \mathrm{g}$ ), sheep and goat milk $(9.2 \mathrm{ng} / \mathrm{g}$ ), with a maximum concentration permitted for infants and young children of $1 \mathrm{ng} / \mathrm{g}$. Concentrations of aromatic hydrocarbons in meat and fish products did not exceed maximum allowable levels [77]. In contrast, another study reported that children's intake levels of PAHs in conventional products were safe. The average PAH intake was $192 \mathrm{ng} /$ day, while the maximum daily intake was $1575 \mathrm{ng} /$ day [78]. A study by Badibostan et al. (2019) evaluated exposure to polycyclic aromatic hydrocarbons in infant and toddler formulas. The authors found that benzopyrene was present in $64.3 \%$ of samples, chrysene in three samples, and fluoranthene in one sample. One product had a concentration of $1.43 \mu \mathrm{g} / \mathrm{kg}$ and that sample exceeded the maximum tolerable limit MTL $(1 \mu \mathrm{g} / \mathrm{kg})$ [79]. On the other hand, some of the studies under review deemed baby products to be safe as regards PAH [80,81].

A summary of the studies on the concentration of PAH is included in Table 10.

Table 10. Summary of studies on the safety of PAH in food for babies.

\begin{tabular}{|c|c|c|c|c|}
\hline $\begin{array}{c}\text { Type of } \\
\text { Contamination }\end{array}$ & $\begin{array}{l}\text { Number of } \\
\text { Samples }\end{array}$ & Type of food Samples & Results & $\begin{array}{c}\text { Country } \\
{[\text { Reference] }}\end{array}$ \\
\hline \multicolumn{5}{|c|}{ CONTAMINANT CONTENT } \\
\hline \multirow[b]{2}{*}{ PAH } & 126 & $\begin{array}{l}{ }^{\mathrm{b}} \text { Commercial food } \\
\text { (meat, fish) }\end{array}$ & $\begin{array}{l}\text { No exceedances in meat and fish, } \\
\text { exceedances in dairy products }\end{array}$ & $\begin{array}{l}\text { Italy } \\
{[77]}\end{array}$ \\
\hline & 40 & $\begin{array}{l}\text { a Infant food, } \\
\mathrm{b} \text { commercial food } \\
\text { (dairy products) }\end{array}$ & $\begin{array}{c}\text { Exceedance in dairy samples } \\
18.2 \% \text {, meat and fish } 5.6 \%\end{array}$ & $\begin{array}{l}\text { Italy } \\
{[76]}\end{array}$ \\
\hline \multicolumn{5}{|c|}{ ESTIMATION OF INTAKE } \\
\hline \multirow{2}{*}{ PAH } & 322 & ${ }^{\mathrm{b}}$ Commercial food (meat) & $\begin{array}{l}\text { No exceedances in average PAH } \\
\text { intake }\end{array}$ & $\begin{array}{l}\text { Estonia } \\
\text { [78] }\end{array}$ \\
\hline & 42 & ${ }^{\mathrm{a}}$ Infant food & One sample exceeding MCL & $\begin{array}{l}\text { Iran } \\
{[79]}\end{array}$ \\
\hline \multicolumn{5}{|c|}{ EXPOSURE } \\
\hline \multirow{2}{*}{ PAH } & 152 & ${ }^{\mathrm{c}}$ Infant formula & No exceedances (MOE > 10,000) & $\begin{array}{c}\text { Korea } \\
{[81]}\end{array}$ \\
\hline & 40 & ${ }^{\mathrm{c}}$ Infant formula & No exceedances (MOE > 10,000) & $\begin{array}{l}\text { Nigeria } \\
\text { [80] }\end{array}$ \\
\hline
\end{tabular}

MCL-Maximum Consumed Limit, MOE—Margin of Exposure, PAH—polycyclic aromatic hydrocarbons, BaP-benzopyrene, $\Sigma$ PAH4, sum of subgroup of four hydrocarbons, a Infant food-products intended for infants up to 12 months of age as complementary foods (cereals, desserts, mousses, wafers, etc.); all solid and liquid foods other than breast milk and infant formula for infants, ${ }^{\mathrm{b}}$ Commercial food-food products intended for consumption by all age groups, ${ }^{\mathrm{C}}$ Infant formula—food products which are represented for special dietary use solely for infants under 12 months of age as replacement human milk.

\subsection{3-Monochloropropane-1,2-Diol (3-MCPD) and Glycidyl Esters}

Beekman et al. (2020) found higher concentrations of 3-MCPD than those of glycidyl esters in 23 samples (10\%). Decreased concentrations of 3-MCPD (about seven-fold lower) and glycidyl esters (about three-fold lower) were noted during a 3-year follow-up, which may be due to the use of new technologies that reduce the risk of contamination. Additionally, higher concentrations of 3-MCPD and glycidyl esters were observed in powdered products than in ready-to-eat ones. Glycidyl is found in vegetable oils, but the highest amounts are found in palm oil [82]. Another study also confirmed lower concentrations of 3-MCPD and glycidyl esters compared to previous years [83]. In a study by Campi et al. (2020), the highest concentrations of 3-MCPD and glycidyl were observed in seed oil, margarine, and cookies. It was also reported that palm oil increased the concentration of MCPD and glycidyl esters in products [84].

Over $71 \%$ of diet and dairy product samples were contaminated with 3-MCPD and glycidyl esters. Estimated daily exposures to bound 3-MCPD $(0.48-0.49 \mu \mathrm{g} \mathrm{kg} / \mathrm{bw})$ and glycidyl esters (1.00-1.11 $\mu \mathrm{g} / \mathrm{kg} / \mathrm{bw} /$ day) did not exceed the limits and did not constitute 
a health risk to children [85]. In another study, the TDI for 3-MCPD was exceeded in a group of children's snacks (mainly potato crisps, crackers, peanuts, and muesli) and the highest concentration was found in biscuits [86]. Interestingly, the authors from the US showed the lowest concentrations of 3-MCPD in products that contained palm oil [87].

A summary of the studies on the concentration of 3-MCPD and glycidyl esters is given in Table 11.

Table 11. Summary of studies on the safety of 3-MCPD and glycidyl esters in food for babies.

\begin{tabular}{|c|c|c|c|c|}
\hline $\begin{array}{c}\text { Type of } \\
\text { Contamination }\end{array}$ & $\begin{array}{l}\text { Number of } \\
\text { Samples }\end{array}$ & Type of Food Sample & Results & $\begin{array}{c}\text { Country } \\
\text { [Reference] }\end{array}$ \\
\hline \multicolumn{5}{|c|}{ CONTAMINANT CONTENT } \\
\hline $\begin{array}{l}\text { Glycidyl esters, } \\
\text { 3-MCPD }\end{array}$ & 275 & $\begin{array}{l}\text { a Infant food (homemade), } \\
{ }^{c} \text { commercial food for toddlers }\end{array}$ & $\begin{array}{c}\text { Over } 71 \% \text { of diet samples } \\
\text { contaminated with } 3-\mathrm{MCPD} \text { and } \\
\text { glycidyl esters }\end{array}$ & $\begin{array}{l}\text { China } \\
\text { [85] }\end{array}$ \\
\hline $\begin{array}{l}\text { Glycidyl esters, } \\
\text { 3-MCPD }\end{array}$ & 222 & ${ }^{\mathrm{a}}$ Infant food & $\begin{array}{c}\text { Lower concentrations of 3-MCPD } \\
\text { (7-fold) and glycidyl esters (3-fold) } \\
\text { during } 3 \text { years }\end{array}$ & $\begin{array}{l}\text { USA } \\
{[82]}\end{array}$ \\
\hline $\begin{array}{l}\text { Glycidyl esters, } \\
\text { 3-MCPD }\end{array}$ & 130 & $\begin{array}{l}\text { a Infant food, } \\
\text { c commercial food }\end{array}$ & $\begin{array}{l}\text { Products containing palm oil had a } \\
\text { higher concentration of 3-MCPD and } \\
\text { glycidyl esters }\end{array}$ & $\begin{array}{l}\text { Italy } \\
{[84]}\end{array}$ \\
\hline $\begin{array}{l}\text { Glycidyl esters, } \\
\text { 3-MCPD }\end{array}$ & 96 & ${ }^{\mathrm{a}}$ Infant food & $\begin{array}{l}\text { Lowest concentrations in products } \\
\text { containing palm oil }\end{array}$ & $\begin{array}{l}\text { USA } \\
{[87]}\end{array}$ \\
\hline $\begin{array}{l}\text { Glycidyl esters, } \\
\text { 2-MCPD, } \\
\text { 3-MCPD }\end{array}$ & 77 & a Infant food & 2-MCPD detected in all samples & $\begin{array}{l}\text { Germany } \\
\text { [83] }\end{array}$ \\
\hline \multicolumn{5}{|c|}{ EXPOSURE } \\
\hline 3-MCPD & 60 & ${ }^{\mathrm{c}}$ Commercial food for toddlers & $\begin{array}{l}\text { Exceeded TDIs in potato chips, } \\
\text { crackers, peanuts, muesli, and biscuits }\end{array}$ & $\begin{array}{l}\text { Poland } \\
\text { [86] }\end{array}$ \\
\hline
\end{tabular}

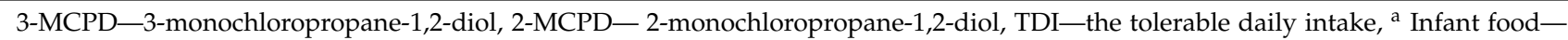
products intended for infants up to 12 months of age as complementary foods (cereals, desserts, mousses, wafers, etc.); all solid and liquid foods other than breast milk and infant formula for infants, ${ }^{\mathrm{C}}$ Infant formula-food products which are represented for special dietary use solely for infants under 12 months of age as replacement human milk.

\subsection{Mineral Oil Hydrocarbons ( $\mathrm{MOHs}$ )}

In a study by Sui et al. (2020), mineral oil hydrocarbons (MOHs) were detected in 17 of 61 samples, with the highest amounts reported in a goat milk-based infant formula [88]. In Zhang's (2019) study, MOHs were found in 66\% of samples, mostly infant formulas [89]. In another study, $\mathrm{MOHs}$ were present in all analyzed samples that contained meat and fish. The highest concentration $(2 \mathrm{mg} / \mathrm{kg} / \mathrm{bw})$ was recorded in a product containing salmon: it exceeded the $\mathrm{MOH}$ standard (maximum limit of $0.6 \mathrm{mg} / \mathrm{kg} / \mathrm{bw}$ ) [8]. Lei et al. (2019) observed the highest risk of $\mathrm{MOH}$ exposure among infants aged 0-6 months and 6-12 months. Additionally, $\mathrm{MOH}$ intake was higher among Europeans and lower among the Chinese, so food contamination with mineral oil hydrocarbons may constitute a health risk for infants from Europe [90].

Table 12 summarizes the studies of mineral oil hydrocarbons in baby food. 
Table 12. Summary of studies on the safety of $\mathrm{MOH}$ in food for babies.

\begin{tabular}{|c|c|c|c|c|}
\hline $\begin{array}{c}\text { Type of } \\
\text { Contamination }\end{array}$ & $\begin{array}{l}\text { Number of } \\
\text { Samples }\end{array}$ & Type of Food Sample & Results & $\begin{array}{c}\text { Country } \\
\text { [Reference] }\end{array}$ \\
\hline \multicolumn{5}{|c|}{ CONTAMINANT CONTENT } \\
\hline \multirow{3}{*}{$\mathrm{MOH}$} & 51 & ${ }^{\mathrm{c}}$ Infant formula & $\mathrm{MOH}$ detected in $33 \%$ & $\begin{array}{c}\text { China } \\
{[88]}\end{array}$ \\
\hline & 50 & ${ }^{\mathrm{c}}$ Infant formula & $\mathrm{MOH}$ detected in $66 \%$ & $\begin{array}{c}\text { China } \\
{[89]}\end{array}$ \\
\hline & 16 & ${ }^{\text {a }}$ Infant food & $\begin{array}{l}\text { MOH detected in all samples } \\
\text { containing meat and fish }\end{array}$ & $\begin{array}{c}\text { Italy } \\
\text { [8] }\end{array}$ \\
\hline \multicolumn{5}{|c|}{ EXPOSURE } \\
\hline $\mathrm{MOH}$ & 230 & 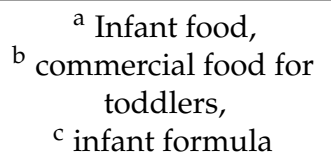 & $\begin{array}{l}\text { Highest risk of } \mathrm{MOH} \text { exposure } \\
\text { among infants }\end{array}$ & $\begin{array}{l}\text { China } \\
\text { [90] }\end{array}$ \\
\hline
\end{tabular}

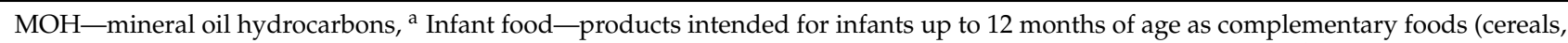
desserts, mousses, wafers, etc.); all solid and liquid foods other than breast milk and infant formula for infants, ${ }^{\mathrm{b}}$ Commercial food for toddlers-snacks intended for children aged 12 to 36 months, ${ }^{c}$ Infant formula—food products which intended for special dietary use solely for infants under 12 months of age as replacement human milk.

\section{Discussion}

Infants and young children are much more vulnerable to contaminants from food. When planning children's diets, it is important to pay attention not only to the quantity but also to the quality of food. Unfortunately, products that are potential sources of contaminants are often also desirable in a healthy diet. Contaminants in foods for infants and toddlers can cause adverse health effects, both in the short term and adulthood.

Exposure to $\mathrm{Pb}$ in infancy disrupts children's development by damaging the nervous system. Long-term exposure to this element, even below relatively safe doses, contributes to impaired concentration and attention, possibly affecting the intelligence quotient (IQ) [91]. Any amount of $\mathrm{Pb}$ in the body disrupts the nervous system. It has been shown that the higher the concentration of $\mathrm{Pb}$ in the blood, the more nervous system disorders develop in children [92]. High amounts of $\mathrm{Pb}$ can be found in meat, fish and seafood, grain products, vegetables, fruit, and dairy products [93].

Cadmium (Cd) features in the International Agency of Research on Cancer (IARC) list of carcinogenic contaminants. Cd damages the renal tubules, contributing to the dysfunction of the excretory system. In addition, it disturbs the acid-base balance and causes endocrine disruption. As in the case of $\mathrm{Pb}$, there are suggestions that doses lower than the TWI (Tolerable Weekly Intake) may also have a neurotoxic effect in children [14]. The main sources of $\mathrm{Cd}$ in foods are grain products, rice-based products, vegetables, fish, and seafood [93]. Mercury (Hg) exposure among infants and young children has a neurotoxic impact through the deleterious effects of methylmercury. Short-term exposure to $\mathrm{Hg}$ may predispose individuals to cardiovascular disorders and contribute to immune system dysfunction. The main sources of $\mathrm{Hg}$ in food are seafood and fish, the highest amounts found in predatory fish [94]. Inorganic As has been classified as a carcinogen. Exposure to As causes skin diseases, nervous system diseases, neurodevelopmental disorders in children, and lung diseases. Long-term exposure can contribute to cardiovascular disease, type 2 diabetes, and cancerous processes. Dietary sources of As exposure include dairy products, rice, and foods for infants and young children [95]. As far as toxic elements in children's diets are concerned, special attention should be paid to products potentially contaminated with $\mathrm{Pb}$ and $\mathrm{Cd}$, because they carry the greatest health risk. It is worth limiting the consumption of rice and rice products, as they are often contaminated with inorganic As. To exceed the maximum intake of As, a 3-year-old child must eat $242 \mathrm{~g}$ of rice cereal per day (6 portions of cereal) or $167 \mathrm{~g}$ of rice waffles, which is about 16.5 pieces [96]. 
Acrylamide is a carcinogenic compound that has been classified as a probable human carcinogen by the IARC. Acrylamide has potent neurotoxic, carcinogenic and genotoxic effects. It disrupts mitochondrial function, leading to cell apoptosis [97]. It also has a toxic influence on enzymatic mechanisms, hormonal balance, muscle function, and fertility. In the case of children, acrylamide mainly comes from heat-treated potatoes (french fries, potato chips, potato pancakes) [98]. Cereals and potato snacks can also be dangerous to this highly sensitive group, so it seems important that remedial steps are taken to reduce the content of acrylamide in infant products.

Bisphenol (BPA) is a substance which, with prolonged exposure, causes endocrine disruption in the body. It is also linked to heart disease, more frequent heart attacks, and ischemic heart disease. BPA exposure is especially dangerous among infants and young children. According to the European Food Safety Authority (EFSA), the TDI is $50 \mu \mathrm{g} / \mathrm{kg} /$ day, but endocrine disruption has been observed at exposures below the TDI [99]. BPA is another substance that may pose a health risk to infants and young children. Changes are needed at the production level to minimize exposure to this contaminant. To reduce bisphenol exposure in children's diets, more home-made foods than prepared baby foods must be consumed. Additionally, food manufacturers should implement bisphenol degradation procedures.

Dioxins are a group of organic compounds which, together with polychlorinated dibenzodioxins and polychlorinated biphenyls, constitute dioxin-like compounds. Dioxins are stored throughout the food chain in adipose tissue. The largest source of exposure, accounting for more than $90 \%$ of exposure, is food, mainly milk, eggs, and meat [39]. Dioxins can be found in breast milk and modified milk-much higher concentrations are observed in breast milk [100]. They cause endocrine disorders, dysfunctions of the central nervous system, fertility problems, and may also contribute to cancer [101]. Many developmental disorders observed in children, including hypotonia, neurodevelopmental and neurobehavioral disorders, lower IQ, hearing disorders, discoloration and dermatological abnormalities, changes in thyroid hormone levels, can be linked to dioxins [102]. As shown in the literature, commercial foods and infant formulas are safe for children in terms of dioxin contamination, as no average intake exceedances have been reported.

Furan has been classified by the IARC as possibly carcinogenic to humans (Group 2B). It is found in stored products that require heat treatment to produce, e.g., bread and pastries, coffee, jarred/canned products, and baby food. Self-prepared meals do not contain furan. Heating food in a closed system causes furan to store in canned and jarred foods. Because of its high volatility, open-system heated meals contain less furan. Furan causes liver damage, kidney damage, and carcinogenic effects [103]. It may be a cause of poorer health among infants and young children, because its estimated intake exceeded the standards in most studies. Practices such as heating food without a lid can greatly minimize this risk.

Mycotoxins are low molecular weight compounds found in cereals and vegetables and their preparations. The most common mycotoxins include: aflatoxins, ochratoxins, fumonisins, and zearalenone. Infants and young children are the most vulnerable to mycotoxins, because they consume large amounts of cereal products in relation to their body weight. Toxin exposure is associated with carcinogenic, nephrotoxic, neurotoxic, hepatotoxic, hormonal, teratogenic, and immunotoxic effects [103]. Mycotoxins cause developmental delay in infants, impaired immune response, gastrointestinal disorders, and also dysfunction in cognitive development. In older children, developmental delays, cognitive and neurological disorders, and learning difficulties are seen [102]. According to the literature, mycotoxin contamination is rare and therefore should not pose a health risk to children.

Sources of nitrate and nitrite in food include nitrogen fertilizer remains, preservative remains from processed foods, and nitrate naturally occurring in green plants as a nitrogen metabolite. Nitrates have no toxic effects, but can convert to nitrites when exposed to bacteria during storage or during digestive processes in the human body. In addition, nitrite reacts with hemoglobin causing oxidation to methemoglobin, which leads to methemoglobinemia in children. This is a dangerous condition for infants because their stomach 
$\mathrm{pH}$ is higher than that of adults, which further facilitates the transformation of nitrates into nitrites. Infants have low expression of NADPH methemoglobin reductase, so the $\mathrm{T}_{1 / 2}$ (half-life) is longer than in adults $[104,105]$. Nitrates and nitrites affect cardiovascular and gastrointestinal homeostasis through nitrogen oxygen conversion. Most nitrates are found in vegetables, such as: beets, radishes, green leafy vegetables, and celery [106]. Meat and meat products, as well as vegetables and fruits present in baby products, are safe in terms of nitrates and nitrites.

Pesticides include dangerous agents such as organochlorine pesticides, as well as less harmful substances. Organochlorine compounds are characterized by a high ability to accumulate and a long half-life, which makes them very toxic to the human body [107]. The sources of human exposure to pesticides are meat, fish, dairy products, and drinking water. The use of certain agents, such as the organochlorine pesticide DDT, is restricted or banned in some countries. These toxins can cause acute or chronic health effects, e.g., neurodegenerative diseases, neurological disorders, pro-oncogenic processes, respiratory disorders, or cardiovascular dysfunctions. Exposure of infants and young children to pesticides can cause neuro-behavioral disorders [108]. Pesticide residues in food, present both in animal and plant products, are also a significant danger. The most effective method to reduce the consumption of pesticides in food is to soak vegetables in a solution of baking soda (10 $\mathrm{g}$ of baking soda and $1 \mathrm{~L}$ of water). Peeling fruits and vegetables, washing in water, refrigeration, blanching, pasteurization, and cooking are also recommended $[109,110]$. These methods should be applied not only by individual consumers but also by producers as part of good manufacturing practices. It seems appropriate to make it obligatory for manufacturers to control pesticide content in commercial products for children.

Polycyclic aromatic hydrocarbons (PAHs) are pollutants with genotoxic effects, possibly carcinogenic to humans. One of the best studied PAH compounds is benzopyrene, classified as group 1 by the IARC. Benzopirene and $\Sigma 4$ PAH (benzopyrene, chrysene, benzoaanthracene, and benzobfluoranthene) are used to determine PAH content in food products [77]. PAHs are not found in unprocessed food, but can be formed during food processing. Polycyclic aromatic hydrocarbons do not seem to constitute a health threat to infants and young children.

3-Monochloropropanol-1,2-diol (3-MCPD) esters and glycidyl esters are impurities that arise during the refining of cooking oils. Esters undergo hydrolysis processes in the gastrointestinal tract, releasing, among other things, 3-MCPD and glycidyl. 3-MCPD has been recognized as a possible human carcinogen by the IARC. Glycidyl has also been found to be a probable human carcinogen (B1), so it is recommended that its consumption should be as low as possible [82]. 3-MCPD and glycidyl esters may pose a risk, but with new technologies this problem is becoming less of a concern, as their concentrations are decreasing.

Mineral oil hydrocarbons $(\mathrm{MOH})$ are a product of petroleum transformation. Contamination of food with $\mathrm{MOH}$ is caused by contaminants associated with food packaging, or contamination of plants and, consequently, vegetable oils [111]. Mineral oil hydrocarbons may cause a health hazard, so more research is needed.

Geographic variation of crops also influences food contamination levels. The content of toxic elements and pesticides is determined by the use of agrochemicals and the industrial activity of a region [112]. For example, the environment in which rice is grown affects the bioavailability of As found in it. Higher levels of As are reported in Bangladesh, China, Taiwan, Vietnam, and Thailand [113]. In the case of mycotoxins, the highest levels of pollution are recorded in certain regions of Africa and Southeast Asia, because of the conditions of tropical and subtropical climate [114]. In a study by Hossain et al. (2015), mycotoxin contamination was observed in North America and Asia, while samples from Europe were contamination-free [115]. High temperature is a major factor in mycotoxin contamination, therefore higher levels are observed in southern Europe than in northern Europe [116]. 


\section{Conclusions}

Dietary diversity in children may indirectly contribute to reducing the risk of exposure to contaminants. Contaminants that have been shown to be potentially dangerous, such as: toxic elements, acrylamide, bisphenol A, pesticides, and $\mathrm{MOH}$, need to be closely monitored.

Children's meals should be as varied as possible, not based on only one food group (e.g., rice) in order not to exceed the doses of toxic elements. To minimize the risk of bisphenol exposure, home-cooked meals are recommended over convenience products for children.

It seems important to provide education for parents and children on how to limit products with potential health hazards and to promote appropriate cooking and preparation techniques that minimize negative health effects. Food safety monitoring should also be increased at the production stage by incorporating good production practices. There is an immediate need for prospective studies that can evaluate cohort-based exposure to contaminants in baby food in the context of the long-term health status of children.

Author Contributions: Conceptualization, K.S. and A.P.-J.; methodology, K.S.; software, A.M.; formal analysis, A.M., K.S. and A.P.-J.; investigation, A.M.; resources, A.M.; data curation, A.M. and A.P.-J.; writing—original draft preparation, A.M.; writing—review and editing, K.S. and A.P.-J.; visualization, A.M. and A.P.-J.; supervision, K.S. All authors have read and agreed to the published version of the manuscript.

Funding: This research received no external funding.

Institutional Review Board Statement: Not applicable.

Informed Consent Statement: Not applicable.

Data Availability Statement: Detailed data are available from the authors.

Conflicts of Interest: The authors declare no conflict of interest. The funders had no role in the design of the study; in the collection, analyses, or interpretation of data; in the writing of the manuscript; or in the decision to publish the results.

\section{References}

1. Patriarca, M.; Menditto, A.; Rossi, B.; Lyon, T.D.; Fell, G.S. Environmental exposure to metals of newborns, infants and young children. Microchem. J. 2000, 67, 351-361. [CrossRef]

2. Makri, A.; Goveia, M.; Balbus, J.; Parkin, R. Children's susceptibility to chemicalas: A review by developmental stage. J. Toxicol. Env. Health B 2004, 7, 417-435. [CrossRef]

3. WHO. Assessment of the Health Risk of Dioxins: Re-Evaluation of the Tolerable Daily Intake (TDI); WHO European Centre for Environment and Health International Programme on Chemical Safety. Available online: https://www.who.int/publications / $\mathrm{m}$ /item/assessment-of-the-health-risk-of-dioxins-re-evaluation-of-the-tolerable-daily-intake-(tdi) (accessed on 25 April 2021).

4. FAO. Safety Evaluation of Certain Contaminants in Food: Furan. World Health Organ. Tech. Rep. Ser. 2011, 8, 487-603.

5. JEFCA. Evaluations of the Joint FAO/WHO Expert Committee on Food Additives, Nitrate; JEFCA: Geneva, Switzerland, 2002.

6. Schecter, A.; Wallace, D.; Pavuk, M.; Piskac, A.; Päpke, O. Dioxins in commercial United States baby food. J. Toxicol. Environ. Health A 2002, 65, 1937-1943. [CrossRef] [PubMed]

7. Feeley, M.; Brouwer, A. Health risks to infants from exposure to PCBs, PCDDs and PCDFs. Food Addit. Contam. 2000, 17, 325-333. [CrossRef]

8. Mondello, L.; Zoccali, M.; Purcaro, G.; Franchnina, F.A.; Sciarrone, D.; Moret, S.; Conte, L.; Tranchida, P.Q. Determination of saturated-hydrocarbon contamination in baby foods by using on-line liquid-gas chromatography and off-line liquid chromatography-comprehensive gas chromatography combined with mass spectrometry. J. Chromatogr. A 2012, 1259, 221-226. [CrossRef]

9. Igweze, Z.N.; Ekhator, O.C.; Orisakwe, O.E. Lead and cadmium in infant milk and cereal based formulae marketed in Nigieria: A probabilistic non-carcinogenic human health risk assessment. Rocz. Panstw. Zakl. Hig. 2020, 71, 303-311.

10. Gardener, H.; Bowen, J.; Callan, S.P. Lead and cadmium contamination in a large sample of United States infant formulas and baby foods. Sci. Total. Environ. 2019, 651 Pt 1, 822-827. [CrossRef]

11. Škrbić, B.; Živančev, J.; Jovanović, G.; Farre, M. Essential and toxic elements in commercial baby food on the Spanish and Serbian market. Food Addit. Contam. Part B 2016, 10, 27-38. [CrossRef]

12. Winiarska-Mieczan, A.; Kiczorowska, B. Determining the content of lead and cadmium in infant food from the Polish market. Int. J. Food Sci. Nutr. 2012, 63, 708-712. [CrossRef] [PubMed]

13. De Castro, C.S.; Arruda, A.F.; Da Cunha, L.R.; SouzaDe, J.R.; Braga, J.W.; Dórea, J.G. Toxic metals (Pb and Cd) and their respective antagonists (Ca and Zn) in infant formulas and milk marketed in Brasilia, Brazil. Int. J. Environ. Res. Public Health. 2010, 7 , 4062-4077. [CrossRef] 
14. Iwegbue, C.M.; Nwozo, S.O.; Overah, L.C.; Nwajei, G.E. Survey of trace element composition of commercial infant formulas in the Nigerian market. Food Addit. Contam. Part B 2010, 3, 163-171. [CrossRef]

15. Gao, Y.; Li, X.; Dong, J.; Cao, Y.; Li, T.; Mielke, H.W. Snack foods and lead ingestion risks for school aged children: A comparative evaluation of potentially toxic metals and children's exposure response of blood lead, copper and zinc levels. Chemosphere 2020, 261, 127547. [CrossRef]

16. Guérin, T.; Chekri, R.; Chafey, C.; Testu, C.; Hulin, M.; Noël, L. Mercury in foods from the first French total diet study on infants and toddlers. Food Chem. 2018, 239, 920-925. [CrossRef]

17. Junqué, E.; Garí, M.; Arce, A.; Torrent, M.; Sunyer, J.; Grimalt, J. Integrated assessment of infant exposure to persistent organic pollutants and mercury via dietary intake in a central western Mediterranean site (Menorca Island). Environ. Res. 2017, 156, 714-724. [CrossRef]

18. Kim, D.W.; Woo, H.D.; Joo, J.; Park, K.S.; Oh, S.Y.; Kwon, H.J.; Park, J.D.; Hong, Y.S.; Sohn, S.J.; Yoon, H.J.; et al. Estimated long-term dietary exposure to lead, cadmium, and mercury in young Korean children. Eur. J. Clin. Nutr. 2014, 68, 1322-1326. [CrossRef] [PubMed]

19. Dabeka, R.W.; McKenzie, A.D. Survey of total mercury in infant formulae and oral electrolytes sold in Canada. Food Addit. Contam. Part B 2012, 5, 65-69. [CrossRef]

20. Martins, C.; Vasco, E.; Paixão, E.; Alvito, P. Total mercury in infant food, occurrence and exposure assessment in Portugal. Food Addit. Contam. Part B 2013, 6, 151-157. [CrossRef] [PubMed]

21. Gu, Z.; de Silva, S.; Reichman, S.M. Arsenic concentrations and dietary exposure in rice-based infant food in Australia. Int. J. Environ. Res. Public Health 2020, 17, 415. [CrossRef]

22. Rothenberg, S.E.; Jackson, B.P.; Carly, M.G.; Donohue, A.; Emmons, A.M. Co-exposure to methylmercury and inorganic arsenic in baby rice cereals and rice-containing teething biscuits. Environ. Res. 2017, 159, 639-647. [CrossRef]

23. Ljung, K.; Palm, B.; Grandér, M.; Vahter, M. High concentrations of essential and toxic elements in infant formula and infant foods-A matter of concern. Food Chem. 2011, 127, 943-951. [CrossRef] [PubMed]

24. Melø, R.; Gellein, K.; Evje, L.; Syversen, T. Minerals and trace elements in commercial infant food. Food Chem. Toxicol. 2008, 46, 3339-3342. [CrossRef]

25. Abt, E.; Robin, L.P.; McGrath, S.; Srinivasan, J.; DiNovi, M.; Adachi, Y.; Chirtel, S. Acrylamide levels and dietary exposure from foods in the United States, an update based on 2011-2015 data. Food Addit. Contam. Part A Chem. Anal. Control. 2019, 36, 1475-1490. [CrossRef] [PubMed]

26. Sirot, V.; Rivière, G.; Leconte, S.; Vin, K.; Traore, T.; Jean, J.; Hulin, M.; Carne, G.; Gorecki, S.; Veyrand, B.; et al. French infant total diet study: Dietary exposure to heat-induced compounds (acrylamide, furan and polycyclic aromatic hydrocarbons) and associated health risks. Food Chem. Toxicol. 2019, 130, 308-316. [CrossRef] [PubMed]

27. Lambert, M.; Inthavong, C.; Hommet, F.; Leblanc, J.C.; Hulin, M.; Guérin, T. Levels of acrylamide in foods included in 'the first French total diet study on infants and toddlers'. Food Chem. 2018, 240, 997-1004. [CrossRef] [PubMed]

28. Elias, A.; Roasto, M.; Reinik, M.; Nelis, K.; Nurk, E.; Elias, T. Acrylamide in commercial foods and intake by infants in Estonia. Food Addit. Contam. Part A Chem. Anal. Control. 2017, 34, 1875-1884. [CrossRef] [PubMed]

29. Mojska, H.; Gielecińska, I.; Stoś, K. Determination of acrylamide level in commercial baby foods and an assessment of infant dietary exposure. Food Chem. Toxicol. 2012, 50, 2722-2728. [CrossRef] [PubMed]

30. Cao. X.L.; Corriveau. J.; Popovic. S.; Clement. G.; Beraldin. F.; Dufresne, G. Bisphenol a in baby food products in glass jars with metal lids from Canadian Markets. J. Agric. Food Chem. 2009, 57, 5345-5351. [CrossRef]

31. Martínez, M.Á.; Castro, I.; Rovira, J.; Ares, S.; Rodríguez, J.M.; Cunha, S.C.; Casal, S.; Fernandes, J.O.; Schuhmacher, M.; Nadal, M. Early-life intake of major trace elements, bisphenol A, tetrabromobisphenol A and fatty acids: Comparing human milk and commercial infant formulas. Environ. Res. 2019, 169, 246-255. [CrossRef]

32. Cirillo, T.; Latini, G.; Castaldi, M.A.; Dipaola, L.; Fasano, E.; Esposito, F.; Scognamiglio, G.; Di Francesco, F.; Cobellis, L. Exposure to di-2-ethylhexyl phthalate, di-N-butyl phthalate and bisphenol A through infant formulas. J. Agric. Food Chem. 2015, 63, 3303-3310. [CrossRef]

33. Niu, Y.; Zhang, J.; Duan, H.; Wu, Y.; Shao, B. Bisphenol A and nonylphenol in foodstuffs: Chinese dietary exposure from the 2007 total diet study and infant health risk from formulas. Food Chem. 2015, 167, 320-325. [CrossRef]

34. Karasauliya, K.; Bhateria, M.; Sonker, A.; Singh, S.P. Determination of bisphenol analogues in infant formula products from India and evaluating the health risk in infants associated with their exposure. J. Agric. Food Chem. 2021, 7, 3932-3941. [CrossRef]

35. Sun, N.; Guo, Q.; Ou, J.B. Simultaneous determination of endogenous hormones and exogenous contaminants in infant formula powdered milk by salting-out assisted liquid-liquid extraction combined with solid-phase extraction purification and UPLCMS/MS. Anal. Methods 2017, 9, 6177-6185. [CrossRef]

36. Saito, K.; Ohmura, A.; Takekuma, M. Assessment of dioxin intake from commercial baby food in infant. Bull. Environ. Contam. Toxicol. 2008, 80, 185-187. [CrossRef] [PubMed]

37. Lorán, S.; Bayarri, S.; Conchello, P.; Herrera, A. Risk assessment of PCDD/PCDFs and indicator PCBs contamination in Spanish commercial baby food. Food Chem. Toxicol. 2010, 48, 145-151. [CrossRef]

38. Sasamoto, T.; Tatebe, H.; Yamaki, Y.; Hashimoto, T.; Ushio, F.; Ibe, A. Estimation of daily intake of PCDDs, PCDFs and Co-PCBs from baby foods. Skokuhin Eiseigaku Zasshi 2006, 47, 157-163. [CrossRef] 
39. Pandelova, M.; Piccinelli, R.; Lopez, W.L.; Henkelmann, B.; Molina-Molina, J.M.; Arrebola, J.P.; Olea, N.; Leclercq, C.; Schramm, K.W. Assessment of PCDD/F, PCB, OCP and BPA dietary exposure of non-breast-fed European infants. Food Addit. Contam. Part A Chem. Anal. Control. 2011, 28, 1110-1122. [CrossRef] [PubMed]

40. Costopoulou, D.; Vassiliadou, I.; Leondiadis, L. Infant dietary exposure to dioxins and dioxin-like compounds in Greece. Food Chem. Toxicol. 2013, 59, 316-324. [CrossRef]

41. Hulin, M.; Sirot, V.; Vasseur, P.; Mahe, A.; Leblanc, J.C.; Jean, J.; Marchand, P.; Venisseau, A.; Le Bizec, B.; Rivière, G. Health risk assessment to dioxins, furans and PCBs in young children: The first French evaluation. Food Chem. Toxicol. 2020, $139,111292$. [CrossRef]

42. De Filippis, S.P.; Brambilla, G.; Dellatte, E.; Corrado, F.; Esposito, M. Exposure to polychlorinated dibenzo-p-dioxins (PCDDs), polychlorinated dibenzofurans (PCDFs), dioxin-like polychlorinated biphenyls (DL-PCBs) and polybrominated diphenyl ethers (PBDEs) through the consumption of prepared meals in Italy. Food Addit. Contam. Part A Chem. Anal. Control. 2014, 31, 1114-1126. [CrossRef]

43. Lambert, M.; Inthavong, C.; Desbourdes, C.; Hommet, F.; Sirot, V.; Leblanc, J.C.; Hulin, M.; Guérin, T. Levels of furan in foods from the first French Total Diet Study on infants and toddlers. Food Chem. 2018, 266, 381-388. [CrossRef]

44. Altaki, M.S.; Santos, F.J.; Puignou, L.; Galceran, M.T. Furan in commercial baby foods from the Spanish market: Estimation of daily intake and risk assessment. Food Addit. Contam. Part A Chem. Anal. Control 2017, 34, 728-739. [CrossRef]

45. Sijia, W.; Enting, W.; Yuan, Y. Detection of furan levels in select Chinese foods by solid phase microextraction-gas chromatography/mass spectrometry method and dietary exposure estimation of furan in the Chinese population. Food Chem. Toxicol. 2014, 64, 34-40. [CrossRef]

46. Scholl, G.; Humblet, M.F.; Scippo, M.L.; De Pauw, E.; Eppe, G.; Saegerman, C. Preliminary assessment of the risk linked to furan ingestion by babies consuming only ready-to-eat food. Food. Addit. Contam. Part A Chem. Anal. Control. 2013, 30, 654-659. [CrossRef] [PubMed]

47. Minorczyk, M.; Góralczyk, K.; Struciński, P.; Hernik, A.; Czaja, K.; Łyczewska, M.; Korcz, W.; Starski, W.; Ludwicki, J. Risk assessment for infants exposed to furan from ready-to-eat thermally processed food products in Poland. Rocz. Panstw. Zakl. Hig. 2012, 63, 403-410. [PubMed]

48. Liu, Y.T.; Tsai, S.W. Assessment of dietary furan exposures from heat processed foods in Taiwan. Chemosphere 2010, 79, 54-59. [CrossRef] [PubMed]

49. Lachenmeier, D.W.; Reusch, H.; Kuballa, T. Risk assessment of furan in commercially jarred baby foods, including insights into its occurrence and formation in freshly home-cooked foods for infants and young children. Food Addit. Contam. Part A 2009, 26, 776-785. [CrossRef]

50. Mallmann, C.A.; Tyska, D.; Almeida, C.A.; Oliveira, M.S.; Gressler, L.T. Mycotoxicological monitoring of breakfast and infant cereals marketed in Brazil. Int. J. Food Microbiol. 2020, 331, 108628. [CrossRef]

51. Saleh, I.; Goktepe, I. Health risk assessment of Patulin intake through apples and apple-based foods sold in Qatar. Heliyon 2019, 5, e02754. [CrossRef]

52. Herrera, M.; Bervis, N.; Carramiñana, J.; Juan, T.; Herrera, A.A.; Ariño, A.; Lorán, S. Occurrence and exposure assessment of aflatoxins and deoxynivalenol in cereal-based baby foods for infants. Toxins 2019, 11, 150. [CrossRef] [PubMed]

53. Postupolski, J.; Starski, A.; Ledzion, E.; Kurpińska-Jaworska, J.; Szczęsna, M. Exposure assessment of infants and young children on selected Fusarium toxins. Rocz. Panstw. Zakl. Hig. 2019, 70, 5-14. [CrossRef]

54. Khoshnamvand, Z.; Nazari, F.; Mehrasebi, M.R.; Hosseini, M.J. Occurrence and safety evaluation of ochratoxin A in cereal-based baby foods collected from Iranian retail market. J. Food Sci. 2019, 84, 695-700. [CrossRef]

55. Ojuri, O.T.; Ezekiel, C.N.; Eskola, M.K.; Šarkanj, B.; Babalola, A.D.; Sulyok, M.; Hajšlová, J.; Elliott, C.T.; Krska, R. Mycotoxin co-exposures in infants and young children consuming household- and industrially-processed complementary foods in Nigeria and risk management advice. Food Control 2019, 98, 312-322. [CrossRef]

56. Omar, S.S. Aflatoxin M1 levels in raw milk, pasteurized milk and infant formula. Ital. J. Food Saf. 2016, 5, 5788. [CrossRef]

57. Sundheim, L.; Lillegaard, I.T.; Fæste, C.K.; Brantsæter, A.L.; Brodal, G.; Eriksen, G.S. Deoxynivalenol exposure in Norway, risk assessments for different human age groups. Toxins 2017, 9, 46. [CrossRef] [PubMed]

58. Er, B.; Demirhan, B.; Yentür, G. Short communication: Investigation of aflatoxin M1 levels in infant follow-on milks and infant formulas sold in the markets of Ankara, Turkey. J. Dairy Sci. 2014, 97, 3328-3331. [CrossRef]

59. Torović, L. Aflatoxin M1 in processed milk and infant formulae and corresponding exposure of adult population in Serbia in 2013-2014. Food Addit. Contam. Part B 2015, 8, 235-244.

60. Li, S.; Min, L.; Wang, G.; Li, D.; Zheng, N.; Wang, J. Occurrence of Aflatoxin M1 in raw milk from manufacturers of infant milk powder in China. Int. J. Environ. Res. Public Health 2018, 15, 879. [CrossRef]

61. Vasco, E.R.; Alvito, P.C. Occurrence and infant exposure assessment of nitrates in baby foods marketed in the region of Lisbon, Portugal. Food Addit. Contam. Part B 2011, 4, 218-225. [CrossRef] [PubMed]

62. Pardo-Marín, O.; Yusà-Pelechà, V.; Villalba-Martín, P.; Perez-Dasí, J.A. Monitoring programme on nitrates in vegetables and vegetable-based baby foods marketed in the Region of Valencia, Spain: Levels and estimated daily intake. Food Addit. Contam. Part A Chem. Anal. Control. 2010, 27, 478-486. [CrossRef] [PubMed]

63. Cortesi, M.L.; Vollano, L.; Peruzy, M.F.; Marrone, R.; Mercogliano, R. Determination of nitrate and nitrite levels in infant foods marketed in Southern Italy. CyTA J. Food 2015, 13, 629-634. [CrossRef] 
64. Rebelo, J.S.; Almeida, M.D.; Vales, L.; Almeida, C.M. Presence of nitrates in baby foods marketed in Portugal. Cogent. Food Agric. 2015, 1, 1010414. [CrossRef]

65. Chetty, A.A.; Prasad, S. Flow injection analysis of nitrate and nitrite in commercial baby foods. Food Chem. 2016, 197 Pt A, 503-508. [CrossRef]

66. Elias, A.; Jalakas, S.; Roasto, M.; Reinik, M.; Nurk, E.; Kaart, T.; Tuvike, A.; Meramäe, K.; Nelis, K.; Elias, T. Nitrite and nitrate content in meat products and estimated nitrite intake by the Estonian children. Food Addit. Contam. Part A Chem. Anal. Control. 2020, 37, 1229-1237. [CrossRef]

67. Mancini, F.R.; Paul, D.; Gauvreau, J.; Volatier, J.L.; Vin, K.; Hulin, M. Dietary exposure to benzoates (E210-E213), parabens (E214-E219), nitrites (E249-E250), nitrates (E251-E252), BHA (E320), BHT (E321) and aspartame (E951) in children less than 3 years old in France. Food Addit. Contam. Part A Chem. Anal. Control. 2015, 32, 293-306. [CrossRef]

68. Reinik, M.; Tamme, T.; Roasto, M.; Juhkam, K.; Jurtsenko, S.; Tenńo, T.; Kiis, A. Nitrites, nitrates and N-nitrosoamines in Estonian cured meat products: Intake by Estonian children and adolescents. Food Addit. Contam. 2005, 22, 1098-1105. [CrossRef] [PubMed]

69. Nougadère, A.; Sirot, V.; Cravedi, J.-P.; Vasseur, P.; Feidt, C.; Fussell, R.J.; Hulin, M. Dietary exposure to pesticide residues and associated health risks in infants and young children-results of the French infant total diet study. Environ. Int. 2020, 137, 105529. [CrossRef] [PubMed]

70. Stepán, R.; Tichá, J.; Hajslová, J.; Kovalczuk, T.; Kocourek, V. Baby food production chain: Pesticide residues in fresh apples and products. Food Addit. Contam. 2005, 22, 1231-1242. [CrossRef]

71. Jeong, Y.; Lee, S.; Kim, S.; Choi, S.D.; Park, J.; Kim, H.J.; Lee, J.J.; Choi, G.; Choi, S.; Kim, S.; et al. Occurrence and exposure assessment of polychlorinated biphenyls and organochlorine pesticides from homemade baby food in Korea. Sci. Total. Environ. 2014, 470-471, 1370-1375. [CrossRef] [PubMed]

72. Torović, L.; Vuković, G.; Dimitrov, N. Pesticide active substances in infant food in Serbia and risk assessment. Food Addit. Contam. Part B 2020, 14, 30-39. [CrossRef] [PubMed]

73. Kapoor, U.; Srivastava, M.K.; Srivastava, A.K.; Patel, D.K.; Garg, V.; Srivastava, L.P. Analysis of imidacloprid residues in fruits, vegetables, cereals, fruit juices, and baby foods, and daily intake estimation in and around Lucknow, India. Environ. Toxicol. Chem. 2013, 32, 723-727. [CrossRef]

74. Gilbert-Lòpez, B.; García-Reyes, J.F.; Ortega-Barrales, P.; Molina-Díaz, A.; Fernández-Alba, A.R. Analyses of pesticide residues in fruit-based baby food by liquid chromatography/electrospray ionization time-of-flight mass spectrometry. Rapid Commun. Mass Spectrom. 2007, 21, 2059-2071. [CrossRef]

75. Panseri, S.; Nobile, M.; Arioli, F.; Biolatti, C.; Pavlovic, R.; Chiesa, L.M. Occurrence of perchlorate, chlorate and polar herbicides in different baby food commodities. Food Chem. 2020, 320, 127205. [CrossRef]

76. Santonicola, S.; Albrizio, S.; Murru, N.; Ferrante, M.C.; Mercogliano, R. Study on the occurrence of polycyclic aromatic hydrocarbons in milk and meat/fish based baby food available in Italy. Chemosphere 2017, 184, 467-472. [CrossRef]

77. Di Bella, C.; Traina, A.; Giosuè, C.; Carpintieri, D.; Lo Dico, G.; Bellante, A.; Del Core, M.; Falco, F.; Gherardi, S.; Uccello, M.M.; et al. Heavy metals and PAHs in meat, milk, and seafood from augusta area (Southern Italy): Contamination levels, dietary intake, and human exposure assessment. Front. Public Health 2020, 8, 273. [CrossRef] [PubMed]

78. Reinik, M.; Tamme, T.; Roasto, M.; Juhkam, K.; Tenno, T.; Kiis, A. Polycyclic aromatic hydrocarbons (PAHs) in meat products and estimated PAH intake by children and the general population in Estonia. Food Addit. Contam. 2007, 24, 429-437. [CrossRef]

79. Badibostan, H.; Feizy, J.; Daraei, B.; Shoeibi, S.; Rajabnejad, S.H.; Asili, J.; Taghizadeh, S.F.; Giesy, J.P.; Karimi, G. Polycyclic aromatic hydrocarbons in infant formulae, follow-on formulae, and baby foods in Iran: An assessment of risk. Food Chem. Toxicol. 2019, 131, 110640. [CrossRef] [PubMed]

80. Iwegbue, C.M.; Edeme, J.N.; Tesi, G.O.; Bassey, F.I.; Martincigh, B.S.; Nwajei, G.E. Polycyclic aromatic hydrocarbon concentrations in commercially available infant formulae in Nigeria: Estimation of dietary intakes and risk assessment. Food Chem. Toxicol. 2014, 72, 221-227. [CrossRef]

81. Han, J.H.; Kim, M.J.; Shin, H.S. Evaluation of polycyclic aromatic hydrocarbon contents and risk assessment for infant formula in Korea. J. Appl. Biol. Chem. 2016, 57, 173-179. [CrossRef]

82. Beekman, J.K.; Grassi, K.; MacMahon, S. Updated occurrence of 3-monochloropropane-1,2-diol esters (3-MCPD) and glycidyl esters in infant formulas purchased in the United States between 2017 and 2019. Food Addit. Contam. Part A 2020, 37, 374-390. [CrossRef]

83. Wöhrlin, F.; Fry, H.; Lahrssen-Wiederholt, M.; Preiß-Weigert, A. Occurrence of fatty acid esters of 3-MCPD, 2-MCPD and glycidol in infant formula. Food Addit. Contam. Part A 2015, 32, 1810-1822. [CrossRef] [PubMed]

84. Di Campi, E.; Di Pasquale, M.; Coni, E. Contamination of some foodstuffs marketed in Italy by fatty acid esters of monochloropropanediols and glycidol. Food Addit. Contam. Part A Chem. Anal. Control. 2020, 37, 753-762. [CrossRef]

85. Jiang, L.; Jing, Z.; Yibaina, W.; Yan, S.; Lili, X.; Yanxu, Z.; Lei, Z. Dietary exposure to fatty acid esters of monochloropropanediols and glycidol of 2- to 3-year-old children attending nursery schools from two areas in China using the duplicate-diet collection method. Food Addit Contam. Part A 2020, 38, 70-80. [CrossRef]

86. Sadowska-Rociek, A.; Surma, M.; Cieślik, E. Analysis of acrylamide, 3-monochloropropane-1,2-diol, its esters and glycidyl esters in carbohydrate-rich products availale on the Polish market. Rocz. Panstw. Zakl. Hig. 2018, 69, 127-137.

87. Leigh, J.; MacMahon, S. Occurrence of 3-monochloropropanediol esters and glycidyl esters in commercial infant formulas in the United States. Food Addit. Contam. Part A 2017, 34, 356-370. [CrossRef] 
88. Sui, H.; Gao, H.; Chen, Y.; Ke, R.; Zhong, H.; Zhong, Q.; Song, Y. Survey of mineral oil hydrocarbons in infant formula from the Chinese market. Food Addit. Contam. Part A 2020, 37, 1040-1048. [CrossRef]

89. Zhang, S.; Liu, L.; Li, B.; Xie, Y.; Ouyang, J.; Wu, Y. Concentrations of migrated mineral oil/polyolefin oligomeric saturated hydrocarbons (MOSH/POSH) in Chinese commercial milk powder products. Food Addit. Contam. Part A 2019, 36, $1261-1272$. [CrossRef]

90. Lei, Z.; Hong, Z.; Yan, F.C.; Jing, L.; Dong, A.; Feng, P.; Jian, B.Z.; Huai, N.Z. Risk Assessment of MOAH and MOSH in infants and young children. Biomed. Environ. Sci. 2019, 32, 130-133.

91. Bodeau-Livinec, F.; Glorennec, P.; Cot, M.; Dumas, P.; Durand, S.; Massougbodji, A.; Ayotte, P.; Le Bot, B. Elevated blood lead levels in infants and mothers in Benin and potential sources of exposure. Int. J. Environ. Res. Public Health 2016, 13, 316. [CrossRef]

92. Téllez-Rojo, M.M.; Bellinger, D.C.; Arroyo-Quiroz, C.; Lamadrid-Figueroa, H.; Mercado-García, A.; Schnaas-Arrieta, L.; Wright, R.O.; Hernández-Avila, M.; Hu, H. Longitudinal associations between blood lead concentrations lower than $10 \mathrm{microg} / \mathrm{dL}$ and neurobehavioral development in environmentally exposed children in Mexico City. Pediatrics 2006, 118, 323-330. [CrossRef]

93. Satarug, S.; Gobe, G.C.; Vesey, D.A.; Phelps, K.R. Cadmium and lead exposure, nephrotoxicity, and mortality. Toxics 2020, 8, 86. [CrossRef] [PubMed]

94. Llop, S.; Murcia, M.; Aguinagalde, X.; Vioque, J.; Rebagliato, M.; Cases, A.; Iňiguez, C.; Lopez-Espinosa, M.J.; Amurrio, A.; Navarrete-Muňoz, M.; et al. Exposure to mercury among Spanish preschool children: Trend from birth to age four. Environ. Res. 2014, 132, 82-92. [CrossRef] [PubMed]

95. Gundert-Remy, U.; Damm, G.; Foth, H.; Freyberger, A.; Gebel, T.; Golka, K.; Röhl, C.; Schupp, T.; Wollin, K.M.; Hengstler, J.G. High exposure to inorganic arsenic by food: The need for risk reduction. Arch. Toxicol. 2015, 89, 2219-2227. [CrossRef]

96. Bielecka, J.; Markiewicz-Żukowska, R.; Nowakowski, P.; Grabia, M.; Puścion-Jakubik, A.; Mielcarek, K.; Gromkowska-Kepka, K.J.; Soroczyńska, J.; Socha, K. Content of toxic elements in 12 groups of rice products available on Polish market: Human health risk assessment. Foods 2020, 9, 1906. [CrossRef] [PubMed]

97. Koszucka, A.; Nowak, A.; Nowak, I.; Motyl, I. Acrylamide in human diet, its metabolism, toxicity, inactivation and the associated European Union legal regulations in food industry. Crit. Rev. Food Sci. Nutr. 2020, 60, 1677-1692. [CrossRef]

98. Semla, M.; Goc, Z.; Martiniaková, M.; Omelka, R.; Formicki, G. Acrylamide: A common food toxin related to physiological functions and health. Physiol. Res. 2017, 66, 205-217. [CrossRef]

99. Schecter, A.; Malik, N.; Haffner, D.; Smith, S.; Harris, T.R.; Paepke, O.; Birnbaum, L. Bisphenol A (BPA) in U.S. food. Environ. Sci. Technol. 2010, 44, 9425-9430. [CrossRef]

100. Hsu, J.F.; Guo, Y.L.; Liu, C.H.; Hu, S.C.; Wang, J.N.; Liao, P.C. A comparison of PCDD/PCDFs exposure in infants via formula milk or breast milk feeding. Chemosphere 2007, 66, 311-319. [CrossRef]

101. Bakhiya, N.; Appel, K.E. Toxicity and carcinogenicity of furan in human diet. Arch. Toxicol. 2010, 84, 563-578. [CrossRef]

102. Kadan, G.; Aral, N. Effects of mycotoxins on child development. Curr. Mol. Pharmacol. 2020, 14, 114.

103. Jones, J.A.; Hopper, A.O.; Power, G.G.; Blood, A.B. Dietary intake and bio-activation of nitrite and nitrate in newborn infants. Pediatr. Res. 2015, 77, 173-181. [CrossRef] [PubMed]

104. Chilaka, C.A.; De Boevre, M.; Atanda, O.O.; De Saeger, S. Fate of Fusarium mycotoxins during processing of Nigerian traditional infant foods (ogi and soybean powder). Food Res. Int. 2018, 116, 408-418. [CrossRef] [PubMed]

105. McMullen, S.E.; Casanova, J.A.; Gross, L.K.; Schenck, F.J. Ion chromatographic determination of nitrate and nitrite in vegetable and fruit baby foods. J. AOAC Int. 2005, 88, 1793-1796. [CrossRef] [PubMed]

106. Johnson, S.F. Methemoglobinemia: Infants at risk. Curr. Probl. Pediatr. Adolesc. Halth Care 2019, 49, 57-67. [CrossRef]

107. Sosan, M.; Adeleye, A.O.; Oyekunle, J.A.; Udah, O.; Oloruntunbi, P.; Daramola, M.; Saka, W.T. Dietary risk assessment of organochlorine pesticide residues in maize-based complementary breakfast food products in Nigeria. Heliyon 2020, 6, e05803. [CrossRef] [PubMed]

108. Anand, N.; Chakraborty, P.; Ray, S. Human exposure to organochlorine, pyrethroid and neonicotinoid pesticides: Comparison between urban and semi-urban regions of India. Environ. Pollut. 2021, 270, 116156. [CrossRef]

109. Bajwa, U.; Sandhu, K.S. Effect of handling and processing on pesticide residues in food- a review. J Food Sci. Technol. 2014, 51, 201-220. [CrossRef]

110. Yang, T.; Doherty, J.; Zhao, B.; Kinchla, A.J.; Clark, J.M.; He, L. Effectiveness of commercial and homemade washing agents in removing pesticide residues on and in apples. J. Agric. Food Chem. 2017, 65, 9744-9752. [CrossRef]

111. Grob, K. Mineral oil hydrocarbons in food: A review. Food Addit. Contam. Part A Chem. Anal. Control. 2018, 35, 1845-1860. [CrossRef]

112. Zhao, K.; Fu, W.; Ye, Z.; Zhang, C. Contamination and spatial variation of heavy metals in the soil-rice system in Nanxun County, Southeastern China. Int. J. Environ. Res. Public Health. 2015, 28, 1577-1594. [CrossRef]

113. Majumder, S.; Banik, P. Geographical variation of arsenic distribution in paddy soil, rice and rice-based products: A meta-analytic approach and implications to human health. J. Environ. Manag. 2019, 233, 184-199. [CrossRef]

114. Ratnavathi, C.V.; Komala, V.V.; Kumar, B.S.V.; Das, I.K.; Patil, J.V. Natural occurrence of aflatoxin B1 in sorghum grown in different geographical regions of India. J. Sci. Food Agric. 2012, 92, 2416-2420. [CrossRef]

115. Hossain, M.Z.; Mari, N.; Goto, T. The relationship between ergosterol and mycotoxin contamination in maize from various countries. Mycotoxin Res. 2015, 31, 91-99. [CrossRef]

116. Paterson, R.R.M.; Venâncio, A.; Lima, N.; Guilloux-Bénatier, M.; Rousseaux, S. Predominant mycotoxins, mycotoxigenic fungi and climate change related to wine. Food Res. Int. 2018, 103, 478-491. [CrossRef] 